\title{
The Current Status of the Preclusive EFFECTS OF JUDGMENTS IN THE FEDERAL Court System of THE UNITED STATES OF AMERICA
}

Accepted

23. 10.2020

Revised

30. 11.2020

Published

21. 12.2020

UDC

$347.953(73)$

Keywords

res

judicata,

merger and

bar,

claim

preclusion,

issue

preclusion,

collateral

estoppel,

finality of

judgments,

US Federal

District

Courts,

civil

procedure.

\author{
THOMAS AlLAN HeLleR \\ University of Michigan, J.D. Wayne Law, Michigan, United States of America. \\ E-mail: heller6651@msn.com
}

CORRESPONDING AUTHOR

heller6651@msn.com

Abstract Res judicata law in the United States of America has a long, extensive and complex history. The aim of this paper is to provide at least a working summary of some of the most important aspects of the current res judicata law in the federal court system of the United States. The flexible discovery, pleading and joinder rules have given rise to more expansive res judicata law. The paper will discuss what exactly constitutes a judgment; how the federal courts deal with finality of judgments in multiple party and multiple claim cases; the final judgment rule; the form of judgments; the methods to enter judgments and significance of entry of judgments; together with a detailed overview of the doctrine of res judicata itself, including the separate, but related twin doctrines of claim preclusion and issue preclusion. 
The aim of this article is to explore the status of the effects of a prior judgment in the federal court system of the United States of America (hereinafter: United States). Most judges and lawyers usually simply refer to this area of law as res judicata, although as will be discussed later in this paper, that is an oversimplification. This topic is broad enough as it is, and it would be completely unwieldly to try to further discuss each state's res judicata law, although to be sure there are many similarities between federal and state law on this topic. ${ }^{1}$ As we shall see, the core aspects of federal res judicata law are fairly well-settled, with much having been written on the topic over the years, both by the courts and by commentators. Indeed, the subject matter was given scholarly consideration in the Restatement (First) of Judgments published in $1942^{2}$ and as subsequently refined in the Restatement (Second) of Judgments published forty years later in 1982. ${ }^{3}$ Further, the U.S. Supreme Court has issued a significant number of cases in which it not only has fully endorsed but also expanded the doctrine ${ }^{4}$ to such an extent that some authors argue that the United States has the most expansive res judicata law in the world (Clermont, 2016: 68). Wright, Miller and Cooper also have published a widely-cited and definitive treatise on res judicata and related issues (Wright and Miller and Cooper, 1981). 5 Other scholarly articles and books abound.

\footnotetext{
${ }^{1}$ Federalism in the United States, as articulated in the United States Constitution, divides power between the federal government and the United States state governments. Article Three of the Constitution established the judicial branch of the federal government. The judicial branch consists of the Supreme Court as well as lower federal courts created by the Congress. The Constitution created only the Supreme Court, and left establishment of inferior courts to Congress. The first of such so-called "inferior" federal courts were established with the Judiciary Act of 1789 (ch. 20, 1 Stat. 73). Article IV of the federal Constitution presupposed the continued existence and operation of state courts. It requires that "full faith and credit [. . .] be given in each State to the [. . . judicial Proceedings of every other State," thus regulating horizontal judicial federalism, and Article VI mandates that "the Judges in every State shall be bound" to recognize the supremacy of federal law, thus regulating vertical judicial federalism. See, U.S Constitution, Art. IV, sec. 1, and Art. VI, sec. 2.

2 The American Law Institute's Restatement (First) of Judgments (1942) (hereinafter "Restatement First") was the seminal effort in the United States to fully and comprehensively analyze and consolidate the American law relating to res judicata and established the doctrines of bar, merger, and collateral estoppel. See Restatement First, $\iint 47-48$, 68.

${ }^{3}$ The Restatement (Second) of Judgments (1982) (hereinafter "Restatement Second") further discussed and refined res judicata jurisprudence and has heavily influenced both the federal and state courts as this area of the law has evolved and crystallized through the years. Courts and commentators alike frequently reference the Restatement as providing guidance.

${ }^{4}$ See e.g., Allen v. McCurry, 101 S. Ct. 411, 449 U.S. 90, 104-05, 66 L. Ed. 2 d 308 (1980) (extending criminal to civil preclusion); Parklane Hosiery Co. v. Shore, 99 S. Ct. 645, 439 U.S. 322, 331-33, 58 L. Ed. 2d 552 (1979) (approving the use of offensive nonmutual collateral estoppel).

${ }^{5}$ Given the sheer breadth of this subject matter, and how concise, well-written, respected and oft-cited this treatise is, especially by the courts, a good deal of the current paper is drawn from this treatise. Indeed, the reader that seeks more information on this subject is urged to consult this treatise along with the Restatement Second, from which this paper also draws heavily.
} 
As defined, refined and clarified throughout the years, American judges and lawyers have a firm grasp on the core aspects of the doctrine of res judicata. And, it is fair to say, given the relatively straightforward rules, bench and bar, at least in most of the usual fact patterns, are able to determine with reasonable certainty when a prior judgment should be given res judicata effect, although it also must be said that even today, and despite the extensive body of law and scholarly commentary, sometimes applying the rules in practice is not always easy. Furthermore, there are certain areas of the law where the doctrine continues to evolve.

The paper will first deal with the issue of exactly what constitutes a final judgment, which is a necessary but not sufficient requirement for the doctrine of res judicata to apply. It will then consider how federal courts deal with the issue of allowing entry of judgment, and thus appeals to be immediately taken, in multi-party and multiclaim litigation. It then will discuss the procedural issues dealing with both the form and entry of judgments. Res judicata includes two related and yet distinct concepts: claim preclusion and issue preclusion. The paper will discuss these twin concepts in turn, together with their necessary elements (Degnan, 1976: 741). ${ }^{6}$

\section{What constitutes a judgement}

The doctrine of res judicata concerns itself with the preclusive effects of a judgment. To have res judicata effects, there first must be a judgment and that judgment must be final. ${ }^{7}$ Before turning to an in-depth discussion of res judicata law, we first need to address the age old questions of what exactly constitutes a judgment and when does it become final. ${ }^{8}$ It is critical for litigants to understand with complete certainty not only what a judgment does and does not encompass but also what constitutes the actual entry of judgment, since the date of entry of final judgment triggers the time for making post-trial motions, appeals and executing upon judgments. These

\footnotetext{
${ }^{6}$ Res judicata legal theory is further complicated by virtue of the fact America has two systems of courts, state and federal. Due to space constraints, this paper will deal only with matters that could arise within the federal courts system. There is an entire body of law that deals with the resolution of issues concerning how preclusion laws apply when both systems are implicated.

${ }^{7}$ Restatement Second (see, n. 3, \13).

8 "There are no hard and fast rules for determining what is a judgment; past cases have set certain boundaries and announced generalizations, but essentially every case must be determined on its own facts." Associated Press v. Taft-Ingalls Corp., 323 F. 2d 114, 115 (C.A.6 1963); Cedar Creek Oil \& Gas Co. v. Fidelity Gas Co., 238 F. 2 d 298 (C.A.9 1956).
} 
matters are governed by the Federal Rules of Civil Procedure (hereinafter "Civil Rules" or "Rule"). ${ }^{9}$

First of all, regarding terminology, Rule 54(a) of the Civil Rules, in defining the word “judgment" states as follows: “Judgment' as used in these rules includes a decree and any order from which an appeal lies." Before 1938, when the Civil Rules were adopted, and merged law and equity, a federal court sitting in equity rendered what was known as a "decree" while an action at law resulted in the entry of a "judgment." Since there is now only one form of action in the federal courts, there is no reason "in preserving any technical distinction between a 'decree' and a 'judgment"' (Wright and Miller and Kane, 1986: $\ 2651) .{ }^{10}$ In other words, Rule 54(a) provides that a judgment at law and a decree in equity are to be treated the same. It is important to note, however, that various procedures or steps in a case occur that culminate in a judgment, as defined in the rule. These earlier steps in the litigation, called the adjudicative phase, result either in a verdict by the jury or a decision by the court. In other words, the terms "decision" and "judgment" are not synonymous. ${ }^{11}$ For instance, in a trial heard by the judge, the decision consists of the court's findings of fact and conclusions of law, which are required under Rule $52 .{ }^{12}$ In a case tried to a

\footnotetext{
${ }^{9}$ The Federal Rules of Civil Procedure govern court procedure for civil cases (rather than criminal cases, which are governed by the Federal Rules of Criminal Procedure) in United States Federal District Courts. Prior to 1938, federal courts had separate rules for civil cases in suits in equity and suits at law. The principal distinctions between law and equity are the panoply of remedies each offers together with the method by which the two are adjudicated. The most common civil remedy a court of law can award is monetary damages. Courts in equity, on the other hand, can enter injunctions or decrees directing someone either to act or to forbear from acting. The other principal difference is the unavailability of a jury in equity; in such cases the judge is the sole trier of fact. In 1938, the Supreme Court issued the current modern rules of civil procedure, abolishing separate rules for equity. The rules have continued to be amended over time.

${ }^{10}$ See also, U.S. v. City of Providence, 492 F. Supp. 602, 604 n. 1 (D.C.R.I. 1980) (An amended consent decree more properly should be called a judgment).

11 " [T] he decision of the Court and the judgment to be entered thereon are not the same things under the Federal Rules of Civil Procedure. The decision is part of the procedure of the trial." Winkelman v. General Motors Corp., 48 F. Supp. 490, 494 (D.C.N.Y. 1942).

12 A sample Findings of Fact and Conclusions of Law (hereinafter "FFCL") can be found on http://blog.pf.um.si/2020/12/05/judgements-in-the-united-states (accessed: 5. 12. 2020), referenced therein as Attachment A. Typically, each party will prepare their own proposed FFCL before trial begins so the trial judge can review them before and during trial. Each party's proposed FFCL reflect what that party expects the facts to show; what they contend the applicable law is; and, what they contend the conclusions of law that necessary follow from the facts proven are. When the judge announces his or her decision, the prevailing party then usually revises the proposed FFCL and sends them to the losing party for review. If the parties agree on the final proposed FFCL they are then submitted to the judge for review and signature. If, as is the more usual situation, the parties have some areas of disagreement in the FFCL, then a hearing is held to resolve those differences. Once resolved, any final changes are made and the judge then signs them. The content of the FFCL are critical for appellate and for res judicata purposes as they encapsulate the issues that were involved in the case; the exact facts the court found as true; and, the conclusions of law that flow from the facts as applied to the applicable law.
} 
jury, the decision phase consists of the jury's verdict. ${ }^{13}$ Critically, however, "the rendition of judgment is the pronouncement of [those] decision[s] and the act that gives [them] legal effect." (Wright and Miller and Kane, 1986: \2651).14

A final judgment is a decision that ends the litigation on the merits and leaves nothing for the court to do but to execute the judgment. A judgment is final when it disposes of all claims, involving all parties to the action. Anything less is not a final judgment. The purpose of the final judgment rule is both to promote efficiency and prevent piecemeal appeals. In the United States, preclusive effect will not be given to rulings or decisions which are only tentative or contingent. ${ }^{15}$ This rule also reflects the deference given to the trial court judges in overseeing trial court litigation. Whether a trial court's decision is final for purposes of appeal, even where no damages are fixed, is typically an ad hoc determination. Whether an order constitutes a final judgment depends on whether the judge has or has not clearly declared his intention in this respect. A final judgment for money must, at the least, determine, or specify the means of determining the amount. There is no finality where one must search the whole record to determine the amount or the facts necessary to compute the amount. A judgment is the final determination of an action and thus has the effect of terminating the litigation. ${ }^{16}$

\section{Judgment upon multiple claims or involving multiple parties}

\subsection{Introduction and Text of Rule}

Since their adoption in 1938, the Civil Rules have allowed for the liberal joinder of parties and claims, meaning that since that time many actions involve both multiple parties and a plethora of claims between those parties. ${ }^{17}$ Rule 54(b) governs entry of judgments in situations where litigation involves multiple claims and/or multiple

\footnotetext{
13 Rule 49 sets forth the rules regarding special verdicts; general verdicts; and, general verdict with answers to written questions. A sample Special Verdict form can be found on http://blog.pf.um.si/2020/12/05/judgments-in-theunited-states/ (accessed: 5. 12. 2020), referenced hereinafter as Attachment B. A sample Special Interrogatory Verdict form is also accessible on said source and referenced hereinafter as Attachment C.

14 See also, Bowles v. Rice, 152 F. 2d 543, 544 (C.A.6 1946) ("Findings of fact and conclusions of law, necessary as they are, are but supplemental to an adjudication").

15 See, Restatement Second (see, n. 3 at $\$ 13 \mathrm{cmt}$. b $\int 14 \mathrm{cmt}$. a).

${ }^{16}$ Catlin v. U.S., 65 S.Ct. 631, 324 U.S. 229, 89 L. Ed. 911 (1945).

17 See, Rule 13 (counterclaims and crossclaims); Rule 14 (Third-Party Practice); Rule 18 (Joinder of Claims); Rule 19 (Required Joinder of Parties); Rule 20 (Permissive Joinder of Parties); Rule 23 (Class Actions); Rule 24 (Intervention).
} 
parties. The purpose of the rule is to permit the entry of judgments upon one or more but fewer than all the parties in an action involving more than one claim or party. Currently, the rule reads as follows. "When an action presents more than one claim for relief - whether as a claim, counterclaim, crossclaim, or third-party claim - or when multiple parties are involved, the court may direct entry of a final judgment as to one or more, but fewer than all, claims or parties only if the court expressly determines that there is no just reason for delay. Otherwise, any order or other decision, however designated, that adjudicates fewer than all the claims or the rights and liabilities of fewer than all the parties does not end the action as to any of the claims or parties and may be revised at any time before entry of a judgment adjudicating all the claims and all the parties' rights and liabilities."

As succinctly explained by Wright and Miller, "[The rule] was adopted because of the potential scope and complexity of civil actions under the federal rules, given their extensive provisions for the liberal joinder of claims and parties. The basic purpose of Rule 54(b) is to avoid the possible injustice of a delay in entering judgment on a distinctly separate claim or as to fewer than all of the parties until the final adjudication of the entire case by making an immediate appeal available" (Wright and Miller and Kane, 1986: \2654). As the Supreme Court stated in Dickinson v. Petroleum Conversion Corp., the liberalization of both pleadings, joinder of parties and claims permitted in one litigated case under the Civil Rules greatly increased the danger of hardship and denial of justice through delay if each issue had to await the determination of all issues as to all parties before a final judgment could enter. ${ }^{18}$ Accordingly, Rule 54(b) attempts to strike a balance between the undesirability of permitting more than one appeal ${ }^{19}$ in a single action while at the same time allowing for interlocutory review in multiple-party or multiple claim situations under narrowly defined circumstances..$^{20}$

\footnotetext{
${ }_{18}$ Dickinson v. Petroleum Conversion Corp., 70 S. Ct. 322, 324, 338 U.S. 507, 511, 94 L. Ed 299 (1950).

${ }^{19}$ Known as interlocutory appeals. Interlocutory appeals are generally frowned upon, as appellate courts greatly prefer, for sake of efficiency, to hear all appellate issues arising from a case at one time, not in piecemeal fashion. ${ }^{20}$ Various courts have explained this rationale. See e.g., Aetna Ins. Co. v. Newton, 398 F. 2 d 729 (C.A.3 1968).
} 
Appellate courts have cautioned the District Courts that they should use great care and restraint when issuing Rule 54(b) "certifications" that judgment should enter and there is no just reason for delay. ${ }^{21}$ While the Rule is permissive in nature, the Supreme Court in Curtiss-Wright Corporation v. General Electric Company ${ }^{22}$ held that in light of the fact the trial judge is in a superior position to assess when to grant Rule 54(b) certifications, the discretionary determination of the District Court should be given "substantial deference" and the reviewing court should disturb the trial court's assessment of the equities only if it can say that the judge's conclusion was "clearly unreasonable." Rule 54(b) applies to all cases governed by the Civil Rules, even admiralty, condemnation, and habeas corpus proceedings (Wright and Miller and Kane, 1986: \2656). Additionally, a final judgment may be entered both on jury verdicts $^{23}$ as well as other decisions by the District Court judge, such as summary judgment orders. ${ }^{24}$

\subsection{Multiple Claims for Relief or Multiple Parties Element}

Three conditions must be met in order for Rule 54(b) to be invoked. As an initial matter, the case must involve either multiple claims for relief or multiple parties. While the issue of whether a case involves multiple parties is obvious, in practice it sometimes has proven more challenging to resolve the question of whether a case presents multiple claims. If claims presented in a case factually are separate and independent, then obviously multiple claims are present (Wright and Miller and Kane, 1986: \2657). ${ }^{25}$ However, in practice it often has proven difficult to tell whether a case involves multiple claims, so that Rule 54(b) applies, or only a single claim supported by multiple grounds, so that the rule does not apply (Wright and Miller and Kane, 1986: \2657). ${ }^{26}$ In 1956, the Supreme Court entertained two cases in which it had to consider the question of what constitutes multiple claims under Rule 54(b). ${ }^{27}$ In Sears, Roebuck \& Company v. Mackey, the complaint contained four counts. The first count sought damages under federal antitrust statutes arising out

\footnotetext{
${ }^{21}$ See e.g., Larson v. Port of New York Authority (D.C.N.Y. 1955), 17 F.R.D. 298.

22 Curtiss-Wright Corporation v. General Electric Company, 100 S. Ct. 1460, 446 U.S. 1, 64 L. Ed. 2 d 1 (1980).

${ }^{23}$ See e.g., Thompson v. Trent Maritime Co., 343 F. 2d 200 (C.A.3 1965).

${ }^{24}$ See e.g., Bushie v. Stenocord Corp., 460 F.2d 116, 118 n. 2 (C.A.9 1972).

${ }^{25}$ See e.g., Dunlop v. Ledet's Foodliner of Larose, Inc., 509 F. 2d 1387, 1388 (C.A.5 1975).

${ }^{26}$ See e.g., Tolson v. U.S., 732 F. 2d 998, 1001 n. 8 (U.S.App.D.C. C.A. 1984).

27 The two cases are: Sears, Roebuck \& Company v. Mackey, 76 S. Ct. 895, 351 U.S. 427, 100 L. Ed. 1297 (1956); Cold Metal Process Company v. United Engineering \& Foundry Company, 76 S. Ct. 904, 351 U.S. 445, 100 L. Ed. 1311 (1956).
} 
of alleged injury to three of his commercial ventures. The remaining three counts, on the other hand, sought recovery on common law grounds for the injury sustained by each of the ventures. The District Court judge dismissed the first two counts and certified them under Rule 54(b). The Supreme Court observed that the second count clearly was independent of counts three and four since it involved a separate business. However, the first count, although it rested on a different legal basis, involved some of the same facts as did the two counts that were not certified. The Court held that "there is no doubt that each of the claims dismissed is a "claim for relief' within the meaning of Rule 54(b), so that their dismissal constitutes a 'final decision' on individual claims." 28 In Cold Metal Process Company v. United Engineering \& Foundry Company, the Court held appealable a certified judgment on plaintiff's claim despite the fact a counterclaim, arising in part out of the same transaction as plaintiff's claim, remained to be tried.

According to Wright, Miller and Kane, although these two Supreme Court decisions failed to provide any significant guidance to answer the question what constitutes “multiple claims" under Rule 54(b), by for example not enunciating a clear test or standard, still, when read together, the Supreme Court at a minimum "repudiate[d] the notion that a separate claim for purposes of Rule 54(b) is one that must be entirely distinct from all the other claims in the action and arise from a different occurrence or transaction" (Wright and Miller and Kane, 1986: \$2657). On the other hand, numerous cases have held that every variation in legal theory does not necessarily constitute a separate "claim." ${ }^{29}$ In the case of Rieser v. Baltimore \& Ohio R.R. Company ${ }^{30}$, the Second Circuit Court of Appeals set forth the following test: "The ultimate determination of multiplicity of claims must rest in every case on whether the underlying factual bases for recovery state a number of different claims which could have been separately enforced." According to Wright, Miller and Kane, this test, while in no way precise, is at least workable and is consistent with the Supreme Court's twin decisions in the Sears and Cold Metal cases (Wright and Miller and Kane, 1986: \2657).

\footnotetext{
${ }^{28}$ Mackey, 78 S. Ct. at 900, 351 U.S. at 436 (per Burton, J).

${ }^{29}$ See e.g., Rabekoff v. Lazere \& Co., 323 F. 2 d 865 (C.A.2 1963).

30224 F. 2d 198, 199 (C.A.2 1955), certiorari denied 76 S.Ct. 651, 350 U.S. 1006, 100 L. Ed. 868 (per Clark, C.J).
} 


\subsection{At Least One Claim or the Rights and Liabilities of at Least One Party Finally Decided Element}

Having discussed the first prerequisite for invoking Rule 54(b), we now turn to the second, which is that at least one claim or the rights and liabilities of at least one party must be finally decided. This does not necessarily mean that the rights and liabilities of a party or the claim must be decided on the merits. Accordingly, for example, the Seventh Circuit held in Blair v. Cleveland Twist Drill Company ${ }^{31}$ that an order dismissing a cross-claim without prejudice under Rule 41 and relegating it to a separate action fell within the ambit of Rule 54(b). Furthermore, dismissals based on lack of subject matter or personal jurisdiction ${ }^{32}$ may dispose of a claim completely, bringing them within the scope of the rule (Wright and Miller and Kane, 1986: \2656). Basically, as the Supreme Court held in Catlin v. U.S., ${ }^{33}$ the standard for whether a decision is final is whether it is one which ends the litigation on the merits and leaves nothing for the court to do except to execute the judgment. In the summary judgment context, this means that a partial summary judgment that decides only some of the issues pertinent to a single claim is not final, but instead interlocutory, and therefore does not come within the scope of the rule ${ }^{34}$ while conversely a decision granting summary judgment that completely disposes of one of several claims is final and can be appealed if the District Court judge issues the necessary certificate under Rule 54(b). ${ }^{35}$

\subsection{No Just Reason for Delay Element}

Finally, regarding the third prerequisite for the issuance of a certificate under Rule 54(b), the court must expressly determine that there is no just reason for delaying the appeal. The Supreme Court has explained that the District Court "is permitted to determine, in the first instance, the appropriate time when each 'final decision' upon 'one or more but less than all' of the claims in a multiple claims action is ready for appeal." 36 While the District Court judge has considerable discretion in deciding whether to issue a Rule 54(b) certificate, given that judge's familiarity with the

\footnotetext{
${ }^{31}$ Blair v. Cleveland Twist Drill Co., 197 F. 2d 842, 845 (C.A.7 1952).

32 See e.g., Tobin Packing Co. v. North Am. Car Corp., 188 F. 2 d 158 (C.A.2 1951).

${ }^{33}$ Catlin v. U.S., 65 S.Ct. 631, 633, 324 U.S. 229, 233, 89 L. Ed. 911 (1945).

34 See e.g., Wynn v. RFC, 212 F. 2 d 953 (C.A.9 1954).

${ }^{35}$ See e.g., Bushie v. Stenocord Corp., 460 F. 2 d 116, 118 n. 2 (C.A.9 1972).

${ }^{36}$ Sears, Roebuck \& Co. v. Mackey, 76 S. Ct. 895, 899, 351 U.S. 427, 435, 100 L. Ed. 1297 (per Burton, J.).
} 
intricacies of the case in the first instance, ${ }^{37} \mathrm{a}$ reviewing court may still nevertheless reverse the decision under an abuse of discretion standard. ${ }^{38}$ At play in making the "no just reason for delay" determination are two competing interests. On the one hand, there is a strong federal policy against interlocutory appeals, that is, piecemeal reviews (Wright and Miller and Kane, 1986: §3907). On the other hand, often there are compelling reasons that the parties should not have to suffer the hardships and injustices through delay that would be alleviated by immediate appeal. ${ }^{39}$ There is no precise standard or test that has been enunciated to guide the District Court judges in making this sometimes admittedly difficult determination. ${ }^{40}$ Accordingly, in determining whether there is any just reason for delay in certifying a decision as ready for immediate appeal, District Court judges are free to consider any factor or reason that is pertinent given the exigencies of the particular case. That said, there is a substantial body of federal case law that has developed that sheds light on what some of these factors are, and we turn to a discussion of those factors next.

One factor the court might consider is the independence between the adjudicated and unadjudicated matters. ${ }^{41}$ This makes logical sense, of course, as requiring an appeals court to review the same facts following a Rule 54(b) certification that it will likely have to consider again if a subsequent appeal is brought after the District Court rules on the non-certified claims runs contrary to the policy against piecemeal appeals and efficiency of appellate court time. In a similar vein, District Court judges should exercise caution in issuing a Rule 54(b) certificate that would require the appellate court to determine questions that remain unadjudicated in the trial court in connection with other claims. ${ }^{42}$ Another factor the courts have taken into consideration is whether future developments in a case might make the need for immediate appellate review moot. Questions regarding mootness have arisen especially with regard to claims involving impleader, ${ }^{43}$ which entail questions concerning indemnification and contribution, and which accordingly might well be

\footnotetext{
3776 S. Ct. 895, 900-901, 351 U.S. 427, 437, 100 L. Ed. 1297 (1956).

38 See also, Curtiss-Wright Corp. v. General Elec. Co., 100 S. Ct. 1460, 446 U.S. 1, 64 L. Ed. 2 d 1 (1980).

${ }^{39}$ Campbell v. Westmoreland Farm, Inc., 403 F. 2d 939, 942 (C.A.2 1968).

${ }^{40}$ Curtiss-Wright Corporation v. General Electric Co., 100 S. Ct. at 1466, 466 U.S. at 10-11 ("because the number of possible situations is large, we are reluctant either to fix or sanction narrow guidelines for the District Courts to follow." Burger, C.J.).

${ }^{41}$ See e.g., Brink's Inc. v. City of New York, 528 F. Supp. 1084 (D.C.N.Y. 1981) (claim and counterclaim unrelated). 42 See e.g., Zangardi v. Tobriner, 330 F. 2d 224, 225, 117 (U.S. App. D.C. 350 C.A. 1964) ("Since the two counts turn on the same question and ask what is for practical purposes the same relief, disposing of one count and leaving the other for future disposition complicates the case and serves no useful purpose.”).

${ }^{43}$ See e.g., Thompson v. Trent Maritime Co., 343 F. 2d 200 (C.A.3 1965).
} 
mooted where the defendant is exonerated from liability in the principal action. ${ }^{44}$ Numerous courts have also held that in issuing a Rule 54(b) certification, the District Court judge must balance whether the benefits of permitting an immediate appeal on the adjudicated matter will outweigh the harmful or prejudicial effects of delaying resolution in the trial court of the unadjudicated issues. For instance, courts will examine whether allowing an immediate appeal on some issues will greatly simplify and facilitate further trial court proceedings after the interlocutory appeal is concluded. ${ }^{45}$ Clearly, utilizing Rule 54(b) to certify matters for immediate appeal, the resolution of which will likely avoid the need for further proceedings in the District Court or which will greatly simplify further trial court proceedings makes great sense, as doing so promotes judicial efficiency. ${ }^{46}$

Finally, the District Court may consider other practical, beneficial effects of permitting an immediate appeal. For instance, in the Curtiss-Wright v. General Electric ${ }^{47}$ case, delay in being able to execute on a judgment may well result in prejudice to the judgment creditor. Accordingly, in situations where the District Court judge holds that a party is entitled to relief on one of multiple claims (for example on a summary judgment in favor of plaintiff under Rule 56), and the only unadjudicated claim is whether the plaintiff will be given additional relief on other claims, it may well be sensible and in the best interests of fairness and justice for the judge to certify the ruling under Rule 54(b) so that the plaintiff has the benefit of recovery that has been awarded, at least so long as doing so does not result in prejudice to the other party. ${ }^{48}$

Of course, the importance of Rule 54(b) in the context of res judicata jurisprudence is that it provides the means for the court to render a final judgment on part of a multiple-claim or multiple-party action, and consequently, once there has been a Rule 54(b) certification and a final judgment has been entered, the time for appeal then begins to run. ${ }^{49}$ And most importantly as far as we are concerned in this paper,

\footnotetext{
44 See e.g., U.S. Fire Ins. Co. v. Smith Barney, Harris Upham \& Co., 724 F. 2 d 650 (C.A.8 1983).

${ }^{45}$ See e.g., Santa Maria v. Owens-Illinois, Inc., 808 F. 2d 848 (C.A.1 1986).

${ }^{46}$ See e.g., Allen v. Colgate-Palmolive Co., 539 F. Supp. 57 (D.C.N.Y. 1981).

47100 S. Ct. 1460,446 U.S. 1 (1980).

${ }^{48}$ See, U.S. v. Kocher, 468 F. 2d 503 (C.A.2 1972), certiorari denied, 93 S. Ct. 1897, 411 U.S. 931, 36 L. Ed. 2 d 390.

49 See e.g., Burkhart v. U.S., 210 F. 2 d 602 (C.A.9 1954).
} 
since res judicata principles are premised on the entry of final judgments, because a Rule 54(b) order is viewed as final, it has res judicata effect. ${ }^{50,51}$

\section{$4 \quad$ Form of judgments}

Prior to 1963, there was no statute or rule that specified the essential elements or form of a final judgment. ${ }^{52}$ Consequently, in many instances there was considerable confusion and uncertainties under federal practice regarding whether various court rulings, such as a court's opinion or memorandum decision, constituted a judgment. Essentially, the resolution of the question whether a court's decision in these various formats should be given the effect of a judgment turned on the subjective intention of the judge, which sometimes could be difficult to discern. ${ }^{53}$ This uncertainty, of course, was problematic for parties and their counsel in determining when a decision or ruling constituted "a judgment" with its attendant legal consequences. To bring some clarity to this conundrum, Rule 58 was amended in 1963 and sets forth the rules concerning both the proper form of judgments and the procedures for entering judgments. Rule 58(a) provides that "Every judgment and amended judgment must be set out in a separate document." Known as the separate document rule, a final order of judgment must be self-contained and not refer, for purposes of completeness of explanation, to other proceedings or other documents. ${ }^{54}$

The Rule does not prescribe the exact form the judgment should take. However, "it is now clear that if this requirement [of a separate document] is not followed, the courts will not look behind the existing papers to try to determine the court's intention and no judgment will exist. The Rule 58 requirement also makes clear that oral statements, until embodied in a writing, are not final judgments" (Wright and Miller and Kane, 1986: $\$ 2652) .55$ The rule contemplates "a simple form of judgment

\footnotetext{
${ }^{50}$ Republic of China v. American Express Co., 190 F. 2d 334 (C.A.2 1951) (Absent a “determination” under Rule 54(b), the District Court's order was not final and could not have any res judicata effect).

51 A sample order Granting Motion for Rule 54(b) Certification can be found on http://blog.pf.um.si/2020/12/05/judgments-in-the-united-states (accessed: 5. 12. 2020), referenced therein as Attachment D.

52 U.S. v. F. \& M. Schaefer Brewing Co., 78 S. Ct. 674, 678, 356 U.S. 227, 233, 2 L. Ed. 2d 721 (1958).

53 See, Forstner Chain Corp., 177 F. 2d 572 (C.A.1 1949).

54 In civil law countries, judgments contain what is known as an Operative Part, which sets forth the bases for the tribunal's judgment. In U.S. federal courts, in order to discern the actual grounds for a decision, the inquiring person or appellate court needs to look beyond the four corners of the judgment to the FFCL in a trial to the judge and to the jury verdict form in matters tried to a jury, and perhaps even to other pleadings in the case record, such as the formal pleadings authorized by Rule 7, and perhaps other matters part of the official court record.

55 See also, Pure Oil Co. v. Boyne, 370 F. 2d 121 (C.A.5 1966).
} 
[...] eschewing the lengthy recitals familiar in state practice" (Wright and Miller and Kane, 1986: \2652). ${ }^{56}$ However, Rule 58(a) must be read in connection with Rule 54(a), which further defines the forms of judgments, and which provides in its second sentence, "A judgment should not include recitals of pleadings, a master's report, or a record of prior proceedings."

Prior to December 1, 2015 Rule 84 set forth official forms of documents, and the rule went on to provide that a judgment drawn pursuant to the Official Forms was valid. However, on that date Rule 84 was abrogated. ${ }^{57}$ Nevertheless, a review of the now abrogated forms does provide guidance. Following the court caption, the document typically will be identified as a "Judgment in a Civil Action." The body of the document then will state, in simple terms, that the plaintiff either recovers an identified amount of money from the defendant, including prejudgment interest at the prevailing rate, which is identified in the judgment, along with costs; or, that the plaintiff recovers nothing from the defendant. If the civil judgment is for something other than or in addition to monetary damages, that relief will be included. The form of judgment also states whether the matter was tried to a jury, to the court, or whether the matters was decided by motion, such as summary judgment. The judgment is then signed by the Clerk of the Court and dated. ${ }^{58}$

\section{$5 \quad$ Procedure for entry of judgment}

We have discussed the judgment itself. A distinction must be made between the written judgment itself and the "filing" or the "entry" of that judgment. Whereas, the judgment itself is the final determination of an action and thus has the effect of terminating the litigation, it is the "entry" of the judgment by the clerk of the court pursuant to Rule 58 that is crucial to the effectiveness of the judgment and for measuring the time periods for appeal and the filing of various post-trial motions. Rule 58(b) sets forth the rules regarding how judgments are entered, with

\footnotetext{
${ }^{56}$ U.S. v. Wissahickon Tool Works, Inc., 200 F. 2d 936, 938 (C.A.2 1952).

57 When the Civil Rules were adopted in 1938, they included Official Forms. In 2015, the Supreme Court ordered Rule 84 abolished, and so the Official Forms were abrogated. This followed work conducted by the Civil Rules Advisory Committee which concluded, on various grounds, that the Official Forms had outlived their usefulness. A good discussion of the history and ultimate abolishment of the Official Forms may be found in a work by Spencer, 2015: 1113-1140.

58 This sample form can be accessed on the United States Courts web page, at uscourts.com (accessed 5. 12. 2020). The form discussed in the text of this article is Form Number: AO 450, entitled "Civil Judgment Forms" which had been effective on November 1, 2011.
} 
distinctions made between judgments entered by the clerk of the court without directions from the court ${ }^{59}$ and those judgments which are entered only after court approval. ${ }^{60}$ Regarding the former, the clerk of the court, without awaiting further direction from the court, must "promptly prepare, sign, and enter the judgment" under three circumstances: (A) "the jury returns a general verdict ${ }^{61}$;" (B) "the court awards only costs or a sum certain" or (C) "the court denies all relief." Situations where the court's approval of the form of judgment is required are governed by Rule 58(b)(2)(A)(B). This rule states in part: "the clerk must, without awaiting the court's direction, promptly prepare, sign, and enter the judgment when: $(A)$ the jury returns a special verdict ${ }^{62}$ or a general verdict with answers to written questions ${ }^{63}$; or (B) the court grants other relief not described in this subdivision (b)."

Rule 58(c), entitled "Time of Entry" states that "judgment is entered at the following times: (1) if a separate document is not required, when the judgment is entered in the civil docket under Rule 79(a); or (2) if a separate document is required, when the judgment is entered in the civil docket under Rule $79(\mathrm{a})$ and the earlier of these events occurs: (A) it is set out in a separate document; or (B) 150 days have run from the entry in the civil docket."

Crucially for our purposes, a judgment in the United States becomes final when the judgment is rendered and the judgment by the rendering court remains the final judgment unless it is overturned by a higher court. ${ }^{64}$ Furthermore, the time for taking an appeal following rendition of the judgment does not impact the judgment's finality. Indeed, a judgment remains final even throughout the time the parties have to seek a review of the judgment by way of a motion in the rendering court or appeal, and beyond that, remains final during the time of review. ${ }^{65}$

\footnotetext{
${ }^{59}$ Rule 58(b)(1)(A), (B) and (C).

${ }^{60}$ Rule 58(b)(2)(A)(B).

${ }^{61}$ A general verdict is a verdict in which the jury decides which party should win the case, but without listing its specific findings on any disputed issue. Such forms are rarely used.

62 A special verdict is a verdict in which the jury gives its findings on factual issues in the case, without necessarily stating which party should win. The judge decides what questions the jury should answer, and the judge can draw legal implications from the jury's answers. See, Attachment B (see, n. 12).

${ }^{63} \mathrm{~A}$ general verdict with interrogatories refers to a general verdict accompanied by answers to written interrogatories (that is, questions) on one or more issues of fact that bear on the verdict. An interrogatory is submitted by the judge to a jury when the court asks for a general verdict and wants to know the bases of the jury's decision. See, Attachment C (see, n.13). Rule 49 governs procedures connected to special verdicts; general verdicts and questions. Obviously, it will be an easier task to determine what issues were actually decided in prior litigation when one can examine findings of fact/conclusions of law and special verdict forms.

${ }^{64}$ Restatement Second (see, n. 3, $\int 13 \mathrm{cmt}$. f).

${ }^{65} \mathrm{Id}$., $\int 14$ and $\mathrm{cmt}$. a.
} 
Stays of enforcement of judgments

Regarding enforcement of a judgment, it should be noted however, that Rule 62 governs stays of proceedings to enforce judgments. Rule 62(a) provides that in most cases ${ }^{66}$ execution on a judgment and proceedings to enforce it are automatically stayed for 30 days after its entry, unless otherwise ordered by the court. Rule 62(b) governs stays by securing a bond or other forms of security. The rule provides: "At any time after judgment is entered, a party may obtain a stay by providing a bond or other security. The stay takes effect when the court approves the bond or other security and remains in effect for the time specified in the bond or other security."

\section{$7 \quad$ Res judicata}

\subsection{Introduction, Terminology and Basic Principles}

Res Judicata jurisprudence has evolved from judge made, common law, following the usual common law system of precedent and stare decisis, and not from legislative mandate (Wright and Miller and Cooper, 1981: \ 4466).67 Federal courts have developed an extensive body of res judicata law, while the various state courts have done the same thing. In many instances, the state courts have adopted rules that either mirror or closely resemble their federal court counterparts, although in some cases there are significant differences. ${ }^{68}$ As stated at the outset of this paper, our discussion will remain limited to a discussion of federal law.

The preclusive effect of a judgment is determined by two related and yet distinct concepts: "claim preclusion" and "issue preclusion". Collectively, these two concepts comprise the doctrine known as "res judicata." Before turning to a detailed discussion of these two concepts, it is worth briefly noting the policies behind res judicata. In its Parklane ${ }^{9}$ decision, the Supreme Court observed that res judicata "has the dual purpose of protecting litigants from the burden of relitigating an identical

\footnotetext{
${ }^{66}$ There are exceptions to the general rule in the case of injunctions, receiverships and patent accounting orders, where there is no automatic stay. See, Rule 62(c)(d).

${ }^{67} \mathrm{It}$ is asserted that Congress has the power to shape federal preclusion rules through legislative action, by for example, enacting "a code of res judicata principles for federal judgments as part of its control over the creation, jurisdiction, and procedure in federal courts" but has chosen not to do so, although a small number of federal statutes in fact speak to issues pertaining to res judicata.

${ }^{68} \mathrm{Id}$. at $\int 4401$.

${ }^{69}$ Parkland Hosiery Co. v. Shore, 99 S. Ct. 645, 649, 439 U.S. 322, 326, 58 L. Ed. 2d 552 (1970).
} 
issue with the same party or his privy and of promoting judicial economy by preventing needless litigation." In the Allen ${ }^{70}$ case, the Court put it a slightly different way: "[R]es judicata and collateral estoppel relieve parties of the cost and vexation of multiple lawsuits, conserve judicial resources, and, by preventing inconsistent decisions, encourage reliance on adjudication." By promoting consolidation, res judicata shields litigants from undue harassment and protects against the substantial time and expense associated with needless and repetitive litigation (Vestal, 1967: 1723). ${ }^{71}$ The reduction of duplicative proceedings similarly promotes the goals of convenience, efficiency and judicial economy; the same trial court presides over unified discovery, all relevant motions, and a single, unified trial. ${ }^{72}$ It also has been said that res judicata preserves the integrity of the courts by helping to foster finality and minimizing the risk of conflicting judgments, which serve only to undermine public confidence in the judicial process. ${ }^{73}$ Commentators have said the doctrine forces both plaintiffs and defendants to take the first trial seriously "and acquit themselves well if there is to be no second chance" (Wright and Miller and Cooper, 1981: \ 4403). However, repose and finality are the core values that res judicata principles seek to promote. ${ }^{74}$ The doctrine applies and the initial judgment controls and is binding even if it was wrong (Currie, 1967: 281, 315). ${ }^{75}$ Accordingly, res judicata applies even in situations where there was error in the initial judgment ${ }^{76}$ and even despite intervening decisions that change the law ${ }^{77}$ including matters taking on constitutional dimensions. ${ }^{78}$ Indeed, principles of res judicata operate with nearly total disregard for what the truth is. To the contrary, they are premised on the belief that litigation must end at some point in time; otherwise, the system would become

\footnotetext{
${ }^{70}$ Allen v. McCurry, 101 S. Ct. 411, 415, 449 U.S. 90, 66 L. Ed. 2 d 308 (1980). In Brown v. Felsen, 99 S. Ct. 2205, 2209, 442 U.S. 127, 60 L. Ed. 2d 767 (1979) the Court also added that the doctrine frees the court time to "resolve other disputes."

71 See, Taylor v. Sturgell, 128 S. Ct. 2161, 553 U.S. 880, 892, 171 L. Ed. 2d 155 (2008) (the Court rejected the opportunity to expand nonparty preclusion rules to include a virtual representation exception, noting that to adopt such an exception would recognize, in effect, "a common-law kind of class action" that would fail to have the procedural protections prescribed for Rule 23 class actions in order to satisfy due process. See detailed discussion of this case in section 7.4.2 of this paper.

72 See, Allen v. McCurry, 101 S. Ct. 411, 449 U.S. 90, 94, 66 L.Ed.2d 308(1980); See also, Conway, M. D. (1993): Narrowing the Scope of Rule 13 [a], University of Chicago Law Review, Vol. 60, pp. 141, 156.

${ }^{73}$ See, Nevada v. United States, 463 U.S. 110, 128-129 (1983).

${ }^{74} \mathrm{Id}$.

${ }^{75} \mathrm{Id}$., Brainerd Currie noted that "the first lesson one must learn on the subject of res judicata is that judicial findings must not be confused with absolute truth."

${ }^{76}$ See e.g., Mitchell v. National Broadcasting Co., 553 F. 2d 265, 272 (C.A.2 1977) (“Otherwise, judgments would have no finality and the core rationale of the rule of res judicata - repose - would cease to exist.").

77 See e.g., U. S. v. Moser, 45 S. Ct. 66, 266 U.S. 236, 69 L. Ed. 2d 262 (1924).

${ }^{78}$ Douglas-Guardian Warehouse Corp. v. Posey, 486 F. 2d 739, 742-743 (C.A.10 1973).
} 
overwhelmed; judgments would not be stable and final; and, constant relitigation would be used as a tool for harassment.

In its brief on Writ of Certiorari to the United State Court of Appeals for the Second Circuit, counsel on behalf of respondent Marcel Fashion Group summarized its argument very eloquently and that summary is worth repeating here. "[Res judicata] serves the public policy that there be an end of litigation, those who have contested a dispute be bound by the result of the contest, and matters that were or could have been resolved in the suit be considered forever settled as between the parties. A contrary view would undermine the finality of judgments and drain party and judicial resources by inviting successive lawsuits." 79 As the Supreme Court stated in Solimino, 80 "[A] losing litigant deserves no rematch after a defeat fairly suffered."

In cases where res judicata applies, the question arises as how the doctrine is asserted, by the parties or by the court. Generally, the answer is that since the U.S. follows an adversarial system, the party invoking the doctrine must either raise it as an affirmative defense or suffer probable waiver. ${ }^{81}$ Trial courts have, rarely, raised res judicata of their own accord. ${ }^{82}$

\subsection{Claim and Defense Preclusion}

\subsubsection{Basic Principles}

Claim preclusion broadly bars the parties or their privies from relitigating issues that were or could have been raised in the initial action. ${ }^{83}$ The doctrine encompasses the law of both merger and bar. If the judgment in the initial action was in the defendant's favor, then the plaintiff's claim is said to be "barred" by the judgment. ${ }^{84}$ If the judgment in the initial action was in the plaintiffs favor, the plaintiffs claim

\footnotetext{
${ }^{79}$ Lucky Brand Dungarees, et al., v. Marcel Fashion Group, Inc., In the Supreme Court of the United States, No. 18-1086, Brief for Respondent, at p. 16.

${ }^{80}$ Astoria Federal Savings \& Loan Association v. Solimino, 501 U.S. 104, 107 (1991).

${ }^{81}$ See, Rule 8 (c). Rule 8 governs the general rules of pleadings and subpart c thereof governs pleading affirmative defenses. Rule 8(c)(1) states: "In responding to a pleading, a party must affirmatively state any avoidance or affirmative defense including: [. . . ] res judicata." See also, Arizona v. California, 120 S. Ct. 2304, 530 U.S. 392 , $412-$ 13, 147 L.Ed.2d 374 (2000) (cautioning trial courts against raising res judicata sua sponte).

82 See e.g., Disimone v. Browner, 121 F. 3d 1262, 1267 (C.A.9 1997).

${ }^{83}$ Cromwell v. County of Sac., 94 U.S. 351, 352, 24 L. Ed. 195 (1876).

${ }^{84}$ See, Restatement Second (see, n. 3, \19).
} 
is said to "merge" in the judgment. ${ }^{85}$ In other words, the doctrine of "merger and bar" preclude the relitigation of all claims falling within the scope of the judgment, regardless of whether or not those claims were in fact litigated (Wright and Miller and Cooper, 1981: $\ 1417) .{ }^{86}$ As one court stated, "Once a claim is reduced to judgment, the original claim is extinguished and merged into the judgment; and a new claim, called a judgment debt, arises." ${ }^{87} \mathrm{Or}$, as stated by Wright, Miller and Cooper: "Foreclosure of matters that never have been litigated has traditionally been expressed by stating that a single 'cause of action' cannot be 'split' by advancing one part in a first suit and reserving some other part for a later suit. The entire cause of action was said to 'merge' in a judgment for the plaintiff, leaving a new cause of action on the judgment, or to be subject to the "bar' of a judgment for the defendant" (Wright and Miller and Cooper, 1981: \4402). In the Cromwell case ${ }^{88}$ the Supreme Court described the general rule of res judicata in the following terms: "The rule provides that when a court of competent jurisdiction has entered a final judgment on the merits of a cause of action, the parties to the suit and their privies are thereafter bound 'not only as to every matter which was offered and received to sustain or defeat the claim or demand, but as to any other admissible matter which might have been offered for that purpose.' The judgment puts an end to the cause of action, which cannot again be brought into litigation between the parties upon any ground whatever, absent fraud or some other factor invalidating the judgment." 89

Clermont, in one of his excellent essays on res judicata ${ }^{90}$ provides the following pragmatic example of how the bar and merger rule works. "So, if P sues D for personal injury resulting from an automobile accident and later, after valid and final judgment, $\mathrm{P}$ sues $\mathrm{D}$ for property damage in the same accident, D can successfully plead claim preclusion under the transactional view." 91

\footnotetext{
${ }^{85}$ Id., $\int 18(1)$.

${ }^{86}$ See e.g., Migra v. Warren City School Dist. Bd. of Educ., 104 S. Ct. 892, 465 U.S. 75, 77 n. 1, 79 L. Ed. 2 d 56 (1984); Monahan v. New York City Dept. of Corrections, 214 F. 3d 275, 285 (C.A.2 2000).

${ }^{87}$ Kotsopoulos v. Asturia Shipping Co., 467 F. 2d 91, 95 (C.A.2 1972).

${ }^{88}$ Cromwell v. County of Sac., 94 U.S. 351, 352, 24 L. Ed. 195 (1876).

${ }^{89}$ Commissioner v. Sunnen, 68 S. Ct. 715, 719, 333 U.S. 591, 597, 92 L. Ed. 898 (per Murphy, J.) (1948).

${ }_{90}$ Clermont, K. M. (2016): Res Judicata as Requisite for Justice, Rutgers University Law Review, Vol. 68, pp. $1107-$ 1108.

${ }^{1}$ The "transactional view" mentioned by Clermont will be discussed in some detail further in this paper so as to bring his quoted example into context.
} 
Just as a plaintiff cannot split her claims, a defendant must assert all available defenses in the initial action. The Supreme Court held in the City of Beloit v. Morgan ${ }^{22}$ case that res judicata bars unlitigated defenses, "[a] party can no more split up defenses than individual demands, and present them by piecemeal in successive suits growing out of the same transaction." 93 By way of example, if a defendant has the potential defenses of the applicable statute of limitations, release, and contributory negligence, all such defenses must be raised in the initial litigation. If such defenses are not raised, then the defendant is precluded from doing so in subsequent litigation under the doctrine of res judicata (Wright and Miller and Cooper, 1981: \4414). ${ }^{94}$

\subsubsection{Discussion of the Elements of Claim Preclusion}

To establish claim preclusion, a party must establish: (1) a final, valid judgment on the merits; (2) identity or privy of parties; and (3) identity of claims in the two actions. ${ }^{95}$ We shall address each of the elements in turn.

\subsubsection{The Validity of the Prior Judgment}

To qualify for preclusion, a judgment must be valid, final, and on the merits. The issue of finality has already been discussed in detail. Regarding the issue of "validity," the basic notion is that judicial actions must achieve a minimum "quality" in order to qualify for res judicata effects (Wright and Miller and Cooper, 1981: \4427). According to Wright, Miller and Cooper in discussing the "validity" element, there are "only four major areas of potential invalidity" requiring examination (Wright and Miller and Cooper, 1981: \4466). The first is whether a judgment entered by the court that lacked subject matter jurisdiction nevertheless has res judicata effects. In such situations, there are competing interests at play. Working against giving such judgments res judicata effects is that there is a strong public policy of ensuring courts act only within their proper limits of competence. On the other hand, if the parties to the initial action received a fair hearing, utilizing correct substantive rules that

\footnotetext{
9274 U.S. (7 Wall.) 619 (1868). See also, Cromwell v. County of Sac., 94 U.S. 351, 352-353 24 L. Ed. 195 (1876) ("defences [that] were not presented in [a prior] action," a "subsequent allegation of their existence" will not be heard in a successive case concerning the same subject matter, because "[t]he judgment is as conclusive, so far as future proceedings at law are concerned, as though the defences never existed.”).

${ }^{93}$ City of Beloit v. Morgan, 74 U.S. (7 Wall.) at 623.

${ }^{94}$ See also, 46 Am. Jur. 2d Judgments $\int 481$ (Am. Jur.) (collecting cases).

95 See e.g., Blonder-Tongue Laboratories, Inc. v. University of Illinois Foundation, 91 S. Ct. 1434, 402 U.S. 313 , 323-324, 28 L.Ed.2d 788 (1971); Chase Manhattan Bank, N.A. v. Celotex Corp., 56 F. 3d 343, 345-346 (C.A.2 1995).
} 
ensured full due process of law, with the only defect being the court lacked subject matter jurisdiction, the counter argument is that there is no fundamental unfairness in cloaking that procedure with res judicata effects (Wright and Miller and Cooper, 1981: \4428). According to Wright, Miller and Cooper and as confirmed in case authorities, "Today, it is safe to conclude that most federal court judgments are res judicata notwithstanding a lack of subject matter jurisdiction" (Wright and Miller and Cooper, 1981: \4428). These authors succinctly explain the rationale for this result: "A lack of subject matter jurisdiction does not of itself depreciate any of the central values of judicial finality. Whether the question is one of enforcing the judgment, applying claim preclusion, or forestalling belated defenses, the mere fact that the court wandered outside its proper orbit suggests less reason to distrust the judgment than application of wrong substantive rules or poor procedure, matters commonly swallowed up in res judicata." 96

Regarding the second area of potential attack, "State judgments may prove somewhat more vulnerable than federal judgments to defeat in subsequent federal litigation" (Wright and Miller and Cooper, 1981: \4428). By way of example, in the case of Ultracashmere House, Ltd., ${ }^{97}$ the court held that a state court default judgment entered in violation of an order staying the state proceeding was not entitled to res judicata effect. On the other hand, when the lack of subject matter jurisdiction is simply a matter of state law, the federal courts have given res judicata effects as dictated by state law (Wright and Miller and Cooper, 1981: $₫ 4428$ ). ${ }^{98}$

Regarding the third major area of potential attack, judgments resting on an unconstitutional statute or judicial ruling, the weight of authority holds that even then such rulings are binding and will be accorded res judicata status (Wright and Miller and Cooper, 1981: \4429). ${ }^{99}$ A leading case is Chicot County Drainage District v. Baxter State Bank ${ }^{100}$ where the Court held that state courts were bound by a municipal debt readjustment accomplished by a federal court under a statute that was later held unconstitutional. The courts justify this outcome on the basis that to conclude

\footnotetext{
${ }^{96}$ See, also, Durfee v. Duke, 84 S. Ct. 242, 375 U.S. 106, 11 L. Ed. 2d 186 (1963); Disher v. Information Resources, Inc., 873 F. 2d 136, 140 (C.A.7 1989) (citing Wright Miller and Cooper) ("[A] court without jurisdiction can render a binding judgment on the merits if the judgment is allowed to become final, unless the lack of jurisdiction is so gross that the judgment is deemed void").

${ }^{97}$ Ultracashmere House, Ltd., 534 F. Supp. 542 (D.C.N.Y. 1982).

${ }^{98}$ See cases catalogued in fn. 33 thereof.

99 See also cases cited therein.

${ }^{100} 60$ S. Ct. 317, 308 U.S. 371, 84 L. Ed. 329 (1940).
} 
otherwise would work an injustice and a hardship upon the previously prevailing party that lawfully acquired vested rights in the form of their state judgments. 101 "So long as the parties were afforded a fair opportunity to raise the question of validity, the judgment should be honored whether the question was not raised or was raised and resolved incorrectly" (Wright and Miller and Cooper, 1981: \4429).

The last major area of attack on a judgment's validity is lack of personal jurisdiction, and it is this line of attack that is most well-settled. "Judgments entered without personal or property jurisdiction can be attacked if there was no appearance in the action, but ordinarily are valid if there was an appearance of any type." This rule was set forth by the Supreme Court in Baldwin v. Iowa State Traveling Men's Association (Wright and Miller and Cooper, 1981: \4430). ${ }^{102}$

\subsubsection{Meaning of On the Merits}

We shall next address the requirement that to obtain res judicata status, the final, valid judgment must also be "on the merits." While this phrase has been used for a long time ${ }^{103}$ and still is used today, as Wright, Miller and Cooper point out, the phrase is misleading, as it suggests that to have preclusive res judicata effects a judgment must rest on a complete examination of the substantive rights asserted in that matter (Wright and Miller and Cooper, 1981: \4435). But while this often is true, such as after a full blown trial and verdict/decision, this is not invariably true. By way of example, Rule 41 governs dismissals of actions. Rule 41 (a) sets forth the procedures for voluntary dismissals, and ordinarily voluntary dismissals do not preclude plaintiff from maintaining a second action. ${ }^{104}$ However, under Rule 41(a)(1)(B) a dismissal may be with prejudice (and hence "on the merits") if the notice or order states it is. And significantly, "if the plaintiff previously dismissed any federal or state court

\footnotetext{
101 See e.g., Douglas-Guardian Warehouse Corp., v. Posey, 486 F. 2d 739, 742-743 (C.A.10 1973).

10251 S. Ct. 517, 283 U.S. 522, 75 L. Ed. 1244 (1931).

${ }^{103}$ See e.g., Hughes v. U.S. 4 Wall. (71 U.S.) 232, 237, 18 L.Ed. 303 (1866).

${ }^{104}$ See, Rule 41(a)(1)(A)(i)(ii) which provides in part that: "the plaintiff may dismiss an action without a court order by filing: (i) a notice of dismissal before the opposing party serves either an answer or a motion for summary judgment; or (ii) a stipulation of dismissal signed by all parties who have appeared." See also, Greenlee v. Goodyear Tire \& Rubber Co., 572 F. 2d 273 (C.A.10 1978) (Holding that under applicable state law, a stipulation of dismissal signed by the parties when plaintiff discovered that an important witness would not be available for trial was without prejudice to instituting a second claim. Of course, any such second claim must be commenced within the period of time as prescribed by an applicable statute of limitations. Otherwise, defendant may interpose the expiry of the statute of limitations as an affirmative defense and seek dismissal of the re-commenced suit on that basis).
} 
action based on or including the same claim, a notice of dismissal operates as an adjudication on the merits."

Rule 41(b) governs what are known as involuntary dismissals. This rule authorizes the court, either on its own motion, or on a motion by the defendant, to dismiss an action where the "plaintiff fails to prosecute or to comply with these rules or a court order." So, for example, if a case lays stagnant for a year and plaintiff makes no effort to move the case forward, the court could dismiss the action under this rule. If a plaintiff fails, by way of another example, to comply with a discovery order the judge might dismiss the plaintiff's complaint as the ultimate sanction. The rule goes on to provide that unless the dismissal order states otherwise, a dismissal under Rule 41(b) "operates as an adjudication on the merits." Accordingly, such an order has res judicata ramifications.

Rule 41(b) also governs situations where the court dismisses actions based upon a lack of subject matter or personal jurisdiction or for improper venue. The rule is clear that such dismissals do not operate as an adjudication on the merits. ${ }^{105}$ Rather, the rule permits plaintiff 106 to commence a second action on the same claim to rectify the deficiency found in the initial action. On the other hand, the judgment in the first action remains effective to preclude the relitigation of the jurisdictional issue that led to the initial dismissal (Wright and Miller and Cooper, 1981: \4436).

One situation that occurs with some degree of frequency, is that a court will dismiss an action under Rule 41, essentially as being premature, where a claimant has failed to first exhaust available administrative remedies. In such situations, the courts have held that claim preclusion does not apply. ${ }^{107}$ And as a general proposition, a second action on the same claim is not precluded by dismissal of a first action in situations where the first action is premature, or there is some other condition that must be undertaken as a precondition to suit. ${ }^{108}$ "No more need be done than await maturity,

\footnotetext{
105 See, Rule 41(b). See also, e.g., Lindy v. U.S., 546 F. 2d 371, 373 (Ct. Cl. 1976) (Holding that dismissal of a claim because of jurisdictional limitations is not res judicata).

106 Assuming the plaintiff has time to commence a second action under any applicable statutes of limitation.

107 See e.g., Fujii v. Dulles, 259 F. 2d 866 (C.A.9 1958) (A second action for a declaration of nationality was not barred by dismissal of the first action for failure to allege adverse administrative action occurring prior to the date of filing the first action.) See also Price v. U.S., 466 F. Supp. 315, 316 (D.C.Pa. 1979) (Dismissal for failure to exhaust administrative remedies does not preclude second action upon exhaustion).

108 Sometimes, for example, pursuant to statute or ordinance, a claimant, before commencing a legal action against a municipality or state, must first give the government notice of the claim, for example, at least $60-90$ days before commencing action. These so-called "notice of claims" laws are designed so as to provide the governing body an
} 
satisfy the precondition, or switch to a different substantive theory that does not depend on the same precondition" (Wright and Miller and Cooper, 1981: \4437). 109

Rule 19 governs the mandatory joinder of parties. ${ }^{110}$ Rule 41(b) explicitly provides that dismissal for the failure to join an indispensable party under Rule 19 does not operate as an adjudication upon the merits, and therefore has no res judicata effects. This rule is in accord with the long-standing common law rule that the dismissal does not bar a new action that merely rectifies the deficiency of parties in the first action. ${ }^{111}$

Judgments by default result in claim and defense preclusion. The reason this is the case is well-stated in Wright, Miller and Cooper and so is worth recapitulating in full: "Valid default judgments establish claim and defense preclusion in the same way as litigated judgments, and are equally entitled to enforcement in other jurisdictions. This consequence follows from the basic functions of default judgments. In one aspect, default judgments afford an opportunity to surrender without incurring the costs of litigation, either because the claim is thought valid or because the cost of litigation seems greater than the probability and rewards of success. Plaintiffs could not afford to accept this surrender if the resulting judgment were not final" (Wright and Miller and Cooper, 1981: \4442).

\footnotetext{
opportunity to investigate the claim and perhaps resolve them short of litigation. See e.g., Revised Code of Washington $\ 4.92 .100$, requiring written notice of claim to state government after injury as condition precedent to later litigation. If the claimant files suit, without first providing the requisite notice, then the suit is subject to dismissal under Rule 41 as being premature, but can be refiled later, assuming the applicable statute of limitations has not expired.

${ }^{109}$ As an example, in Pfeiffer Co., v. U.S., 385 F. Supp. 367, 371, E. D. Mo. (1974), affirmed 518 F. 2 d 124 (C.A.8 1975) the court held dismissal of a tax refund claim for failure to demand a refund first did not preclude a second action after a claim for refund had been filed.

${ }^{110}$ Rule 19(a), dealing with mandatory joinder, provides that "A person who is subject to service of process and whose joinder will not deprive the court of subject-matter jurisdiction must be joined as a party if: (A) in that person's absence, the court cannot accord complete relief among existing parties; or (B) that person claims an interest relating to the subject of the action and is so situated that disposing of the action in that person's absence may; (i) as a practical matter impair or impede the person's ability to protect the interest; or (ii) leave an existing party subject to a substantial risk of incurring double, multiple, or otherwise inconsistent obligations because of the interest."

111 See e.g., Hughes v. U.S., 4 Wall. (71 U.S.) 232, 237, 18 L.Ed. 303 (1866) (Dismissal of a prior action for defect of parties is not a judgment on the merits).
} 


\subsubsection{Meaning of Parties and Those Privy to a Party}

Traditionally, it has been the rule that a judgment is binding and preclusion only applies to parties and persons in "privity" with them. Conversely, the general principle is that nonparties are not bound (Wright and Miller and Cooper, 1981: \ 4448-4449). However, as will be discussed, there are numerous important exceptions to these general rules. This matter will be discussed later in this paper at section 7.4.

\subsubsection{Identity of Claims}

The third element required to establish claim preclusion is identity of claims in the two actions. The Supreme Court has not enunciated any precise test for determining whether there is an identity of claims, for purposes of claim preclusion, and nor have the lower federal courts applied any uniform standard. ${ }^{112}$ Before the Civil Rules were adopted, courts adhered to "[t]he old theory of narrowing the issue down [...] to one single limited matter," thereby "forcing the parties to bring separate actions." 113 This procedure was awkward and inefficient, as it required litigation of claims in piecemeal fashion, and exalted the litigation of very narrow issues to the exclusion of more comprehensive proceedings. ${ }^{114}$ In substantial part, this was due to the fact that before the Civil Rules were adopted in $1938^{115}$ there were severe procedural restraints, such as rigid joinder and pleading rules which either severely restricted or prevented consolidation of claims. ${ }^{116}$ This policy found support in the idea that "[a] defendant should not be required to assert his claim in the forum or the proceeding chosen by the plaintiff but should be allowed to bring suit at a time and place of his own selection." 117 In short, the old view defined the term "claim"

\footnotetext{
112 See e.g., Nevada v. United States, 103 S. Ct. 2906, 463 U.S. 110, 130 n. 12, 77 L. Ed. 2d 509 (1983); I.A.M. National Pension Fund, Benefit Plan A v. Industrial Gear Manufacturing Co., 723 F. 3d 944, 947-948 (D. DC. 1983).

113 Williamson v. Columbia Gas \& Elec. Corp., 186 F. 2d 464, 469 (C.A.3 1950).

114 Restatement Second (see, n. 3, \19).

115 The adoption of the Federal Rules of Civil Procedure in 1938 replaced the earlier procedures under the Federal Equity Rules and the Conformity Act (28 USC 724 (1934)). The Conformity Act required that procedures in suits at law conform to state practice, usually the Field Code or a pleading system based on common law. Before the Civil Rules were established, common law pleading was more formal, traditional, and particular in its phrases and requirements. For example, a plaintiff bringing a trespass suit would have to mention key phrases in his complaint or risk having it dismissed with prejudice.

116 Restatement Second (see, n. 3, \24, cmt. A); See also, Williamson v. Columbia Gas \& Elec. Corp., 186 F. 2 d at 469.

117 Restatement Second (see, n. 3, \22, comm. A). At the time, the prevailing attitude was that defendant's rights to choose his or her own forum and time to bring counterclaims outweighed interests such as efficiency and judicial economy.
} 
extremely narrowly, and in terms of one single theory or substantive right. Additionally, the courts used the term "cause of action" and not "claim". 118 Accordingly, as a result of the courts so narrowly construing the concept of "claim," the effects of res judicata were in turn highly limited, and this resulted in piecemeal litigation and a low risk of preclusion. ${ }^{119}$

Over time, however, the federal courts significantly expanded the old common law notion of what constitutes the same cause of action for purposes of claim preclusion. Therefore, the earlier common law rule favoring claim isolation and party autonomy has been supplanted by a new philosophy that limits the number of lawsuits possible over one controversy. Modern courts have done this by significantly broadening the notion of the scope of a "claim." 120 This evolution and expansion of the meaning of the term "claim" coincided with, and to a large extent was promoted by, the evolution of the modern federal court civil procedural rules, most of which have been discussed in this paper, namely joinder and pleading reforms that operate in conjunction to urge, if not require, consolidation of related claims into a single action. ${ }^{121}$

Rule 13 of the Civil Rules, not previously discussed, is important in this regard. Rule 13 governs the pleading requirements for counterclaims. It requires a defendant to plead certain related claims. Specifically, Rule 13(a) provides, in pertinent part, that a counterclaim is compulsory if it "arises out of the transaction or occurrence that is the subject matter of the opposing party's claim" (emphasis added). While the text of Rule 13(a) is silent on the consequences that will ensue for the failure to plead a compulsory counterclaim, it is well-accepted that a party who fails to plead a compulsory counterclaim is barred from raising that claim in a later action in federal court (Wright and Miller and Cooper, 1981: \1417). This rule was designed "to flush out all possible counterclaims early in the litigation; in other words to prevent multiplicity of actions and to achieve a just resolution in a single lawsuit of all

\footnotetext{
118 Id., \ 24, cmt. a.

${ }^{119}$ See, Williamson v. Columbia Gas \& Elec. Corp., 186 F. 2d at 469.

120 See, Williamson v. Columbia Gas \& Elec. Corp., 186 F. 2d at 469 (“[T]he meaning of 'cause of action' for res judicata purposes is much broader today than it was earlier."); See also, Restatement Second (see, n. 3, cmt. A) (“The present trend is to see claim in factual terms and to make it coterminous with the transaction regardless of the number of substantive theories or variant forms of relief flowing from those theories, that may be available to the plaintiff; regardless of the variations in the evidence needed to support the theories or rights").

${ }^{121}$ See, Williamson v. Columbia Gas \& Elec. Corp., 186 F. 2d at 469-470.
} 
disputes arising out of common matters." 122 Rule 13 accordingly has a claim preclusive effect in federal court, providing an "independent basis" to bar claims that should have been presented in a prior action. ${ }^{123}$ In sum, as the many procedural devices under the Civil Rules have broadened the scope of claims that either may or in some case must be litigated together, the scope of claims covered by res judicata has significantly widened.

Modern res judicata jurisprudence has called for a much broader standard for determining whether multiple claims, or claim(s) and a counterclaim, are the "same" for purposes of claim preclusion. In this regard, the clear trend has been towards the adoption of what is called a "transactional analysis." 124 As stated by the court in one case, 125 " $[\mathrm{w}]$ hether or not the first judgment will have preclusive effect depends in part on whether the same transaction or series of transactions is at issue, whether the same evidence is needed to support both claims, and whether the facts essential to the second were present in the first." As stated by another court, "To ascertain whether two actions spring from the same "transaction' or 'claim," courts look to "whether the underlying facts are 'related in time, space, origin, or motivation, whether they form a convenient trial unit, and whether their treatment as a unit conforms to the parties' expectations or business understanding or usage." 126 In other words, "the question is whether the claim was sufficiently related to the claims in the first proceeding that it should have been asserted in that proceeding." 127 The Supreme Court has recently explained ${ }^{128}$ that the question of whether the causes of action in successive suits are the "same" for purposes of res judicata depends on whether they concern a "common nucleus of operative fact." In other words, whether they concern the same "transaction, or series of connected transactions." 129

\footnotetext{
${ }^{122}$ Cyclops Corp., v. Fischbach \& Moore, Inc., 71 F.R.D. 616, 619 (W.D.Pa 1976), citing 3 Moore’s Federal Practice, 13.12 [1] (1974).

${ }^{123}$ Polymer Industrial Products Co. v. Bridgestone/Firestone, Inc., 211 F.R.D. 312, 318 (N.D. Ohio 2002), aff'd 347 F. 3d 935 (Fed Cir. 2003 en banc).

${ }^{124}$ See, Wagner, ALR Fed. 829, \ 2 [a]; Restatement Second (see, n. 3, \$24, cmt. A).

125 Monahan v. New York City Dept. of Corrections, 214 F. 3d 275, 285 (C.A.2 2000).

${ }^{126}$ Pike v. Freeman, 266 F. 3d 78, 91 (C.A.2 2001); See also, ex rel. Ross v. Board of Educ. of Tp. High School Dist. 211, 486 F. 3d 279 (C.A.7 2007).

${ }_{127}$ Pike v. Freeman, 266 F. 3d at 91.

${ }_{128}$ Currier v. Virginia, 138 S. Ct. 2144, 2154, 585 U.S. (2018).

${ }^{129}$ Restatement Second (see, n. 3, \24(1)). Or, as stated by Wright and Miller and Cooper, 1981: 4407, "the question boils down to whether the 'gist' of the two actions is the same," so that "a different judgment in the second action would impair or destroy rights or interests established by the judgment entered in the first action." If they do, then the causes of action are the same and preclusion rules apply.
} 
A leading scholar on res judicata jurisprudence boils down the law regarding the identity of claims element succinctly and so his analysis is well worth repeating here in some detail (Clermont, 2016: 1107-1108). “America's new 'transactional' view is that a claim includes all rights of the plaintiff to remedies against the defendant on any theory with respect to the transaction from which the action arose [...] Still, a claim will be big enough to include: (1) different harms; (2) different evidence; (3) different legal theories, whether cumulative, alternative, or even inconsistent; (4) different rights and remedies, whether legal or equitable; and (5) a series of related events [...]. The transactional view rests on the idea that the plaintiff should in a single lawsuit fully litigate his or her grievances arising from a transaction, considering that under the modern and permissive rules of procedure the plaintiff may do so. This requirement increases efficiency, with an acceptable burden on fairness. Accordingly, the plaintiff must be careful to put any asserted claim entirely before the court, because judgment will not only preclude actual relitigation, but also preclude later pursuit of the claim's unasserted portion, that is, the part that could have been, but was not, litigated. Any plaintiff who asserts only a part of the claim is said to have impermissibly split the claim" (Clermont, 2016: 1107-1108).

\subsection{Issue Preclusion}

\subsubsection{Introduction and Basic Rule of Issue Preclusion}

Clermont's exposition on the rationale of issue preclusion, and how that doctrine differs from claim preclusion, is also particularly instructive. "Claim preclusion aims at limiting the number of lawsuits that may be brought with respect to the same controversy. If claim preclusion applies, a second lawsuit on the same claim will wholly terminate, regardless of what issues were or were not litigated in the first lawsuit. By contrast, U.S. issue preclusion concerns only repeated litigation of the same issues. Thus, issue preclusion would apply only if claim preclusion were inapplicable, either because an exception to claim preclusion applied or because a different claim was in suit. While the core of claim preclusion is necessary, issue preclusion in the United States is not a necessary doctrine, but rather the product of policy determinations in favor of finality (Clermont, 2016: 1114)."130

${ }^{130}$ Citing Field, H. R., et al. (2014): 668. 
Wright, Miller and Cooper articulate the difference between claim and issue preclusion in the following helpful terms. "As compared to claim preclusion, the rules of issue preclusion do not purport to prohibit litigation of matters that never have been argued or decided. Whether the label applied be the modern term of issue preclusion, the still current phrases of collateral estoppel and direct estoppel, or more antique names, the principle is simply that later courts should honor the first actual decision of a matter that has been actually litigated" (Wright and Miller and Cooper, 1981: \ 4416). These authors rightly and justifiably comment that the law in this area is so complicated and that so many limitations, caveats, and permutations exist that it is difficult and indeed nearly impossible to achieve any concise statement of the rule "that is both graceful and complete" (Wright and Miller and Cooper, 1981: \4416). Given that quite candid acknowledgment, and given further that the aim of this paper is to at least explain the fundamentals of preclusion jurisprudence in the United States federal courts in a fashion that is hopefully reasonably concise, so that the reader can at least appreciate the core principles of the law, this author has decided that utilizing the admittedly lengthy (and yet still succinct) summary of the doctrine of issue preclusion set forth by Wright, Miller and Cooper made the most sense.

"[ $[$ ssue preclusion arises in a second action on the basis of a prior decision when the same 'issue' is involved in both actions; the issue was 'actually litigated' in the first action, after a full and fair opportunity for litigation; the issue was 'actually decided' in the first action, by a disposition that is sufficiently 'final,' 'on the merits,' and 'valid'; it was necessary to decide the issue in disposing of the first action, and in some decisions - the issue occupied a high position in the logical hierarchy of abstract legal rules applied in the first action; the later litigation is between the same parties or involves nonparties that are subject to the binding effect or benefit of the first action; the role of the issue in the second action was foreseeable in the first action, or it occupies a high position in the logical hierarchy of abstract legal rules applied in the second action; and there are no special considerations of fairness, relative judicial authority, changes of law, or the like, that warrant remission of the ordinary rules of preclusion. Once these requirements are met, issue preclusion is available not only to defend against a demand for relief, but also in offensive support for a demand for relief. Issue preclusion, moreover, is available whether or not the second action involves a new claim or cause of action. If the second action involves the same claim or cause of action as the first, issue preclusion may be called direct 
estoppel. If a new claim or cause of action is involved, issue preclusion is commonly called collateral estoppel” (Wright and Miller and Cooper, 1981: \4416).

Clermont states the rule and its elements in the following terms: "Outside the context of the initial action, a party (or privy) generally may not litigate the same issue of fact or law (or the same mixed issue of law and fact) that was actually litigated and determined therein if the determination was essential to a valid and final judgment. Indeed, U.S. issue preclusion applies in a second action brought on the same claim (direct estoppel) or on a different claim (collateral estoppel) [...] In brief, when claim preclusion does not apply, issue preclusion acts to prevent inappropriate relitigation of essential issues. That is, issue preclusion reaches only the same issues that were actually litigated and determined, not those that were defaulted, admitted, stipulated, or consented; and issue preclusion reaches only essential determinations, not dicta or other asides. This doctrinal statement implies three requirements for application of issue preclusion: (1) same issue, (2) actually litigated and determined, and (3) essential to judgment" (Clermont, 2016: 1114-1115). ${ }^{131}$ We shall now address each of these elements, in turn.

\subsubsection{Discussion of Same Issue Element}

Regarding the "same issue" element of issue preclusion, the Restatement Second of Judgments explain that under the modern view, the scope of what constitutes an issue should be viewed through the lens of the efficiency and fairness rationale of res judicata. The question whether a matter sought to be raised in a subsequent action constitutes the same issue as presented in the first action is a pragmatic question, turning on a variety of factors such as "the degree of overlap between the factual evidence and legal argument advanced with respect to the matter in the initial action and that to be advanced with respect to the matter in the subsequent action." 132 If a different legal standard applies in the second action or a change in the facts, then the issue is in fact different and issue preclusion does not apply. ${ }^{133}$

\footnotetext{
${ }^{131}$ Citing to Restatement Second (see, n. 3 at $\ 27$ ).

${ }^{132}$ Id.

${ }^{133} \mathrm{Id}$.
} 
It should also be noted that differences in the burden of proof in the successive litigations may well result in a finding that the issues presented in both suits are not identical. This is so because, logically, if the burden of proof differs, there can be no assurance that the result would be the same in both actions and the requirements of collateral estoppel are designed to provide that very assurance. This issue arises often when there are criminal and civil actions that stem from the same incident, for example, a fight in a bar or a murder that gives rise to both a criminal action and tort action. In the United States in criminal suits the prosecution must prove each element beyond a reasonable doubt, whereas in civil actions the plaintiff need only establish the claim by a preponderance of the evidence, or, more probable than not. If, in this setting, an issue is established first under the stricter standard, then it may be given collateral estoppel effect in the later civil proceeding.

\subsubsection{Discussion of Actually Litigated and Determined Element}

The second element of the doctrine, namely "actually litigated and determined" is taken quite literally. In practical terms, what this means is that the doctrine can result following a trial on the merits, or following a ruling on a motion (such as a motion for summary judgment under Rule 56, which typically is decided based on pleadings, affidavits/declarations, admissions, discovery responses etc.) decided on papers and perhaps oral argument, but issue preclusion will not follow from an admission or stipulation or from a default or consent judgment (Clermont, 2016: 1117). ${ }^{134}$ Some courts have held that both judgments taken by default ${ }^{135}$ or consent ${ }^{136}$ satisfy the "actually litigated and determined" standard on the theory that "the truth of all the facts alleged by the plaintiff and necessary to the recovery are raised by plaintiffs pleading, and the defendant should not be able to escape the effect of judgment by waiving the right to contest them" in the case of a default judgment, or, by essentially agreeing to them in the case of a consent judgment (Clermont, 2016: 1117). Clermont takes issue with these rulings, observing that "these cases' approach is not only unfair and inefficient, but also fictional in treating as established many matters that were

\footnotetext{
134 Clermont notes in his paper that some courts have in fact applied issue preclusion to default and consent judgments, but he argues the rationale used by such courts "is not only unfair and inefficient, but also fictional in treating as established many matters that were never decided. Although a default or consent judgment can have claim preclusion effect, it should not generate issue preclusion.”

${ }^{135}$ See e.g., Lynch v. Lynch, 94 N.W. 2d 105, 109 (Iowa 1959).

${ }^{136}$ See e.g., Township of Washington v. Gould, 189 A.2d 697, 700-01 (N.J. 1963).
} 
never decided. Although a default or consent judgment can have claim preclusion effect, it should not generate issue preclusion" (Clermont, 2016: 1117).

\subsubsection{Discussion of Essential (Necessary) to Judgment Element}

Issue preclusion attaches only to determinations that were necessary or essential to support the judgment entered in the first action (Wright and Miller and Cooper, 1981: \4421). According to the Restatement Second "When an issue of fact or law is actually litigated and determined by a valid and final judgment, and the determination is essential to the judgment, the determination is conclusive in a subsequent action." 137 The flip side of the essential/necessary to judgment coin is that if a determination of fact or law in the prior action was merely incidental to that action, then there is no issue preclusion. While a mere reading of this rule itself may seem straightforward, in practice applying this rule has often caused great difficulty. However, the rationale for the rule is clear. It assures that the parties in the first action vigorously litigated the issue so that there is no unfairness in preventing the relitigation of that issue in a second action as there would be little likelihood that the results in the second action would be any different.

In some situations, it is clear that resolution of particular issues was not necessary to the judgment in a prior action. For example, a jury's special verdict may resolve matters of fact that are then found immaterial to the controlling legal issues in the second action. In such a case, the special verdict does not preclude the same matters of fact in later litigation. ${ }^{138}$ In another clear situation, it often happens that a court will actually state that it is indulging in mere dictum that should not have preclusive effect in later litigation. 139 "In other settings, it may be necessary to undertake a more detailed inquiry to understand how specific findings came to be made and to determine whether they were necessary to the first judgment. If the inquiry reveals that the matters had 'come under consideration only collaterally or incidentally,' preclusion is denied" (Wright and Miller and Cooper, 1981: \4421). ${ }^{140}$

\footnotetext{
${ }^{137}$ Restatement Second (see, n. 3 at $\left.\$ 27\right)$.

138 See e.g., Smith v. McCool, 16 Wall. (83 U.S.) 560, 21 L. Ed. 324 (1873).

${ }^{139}$ See e.g., In Parmelee Transp. Co. v. U.S., 351 F. 2d 619, 621 n. 1, 173 Ct. Cl. 139 (1965).

${ }^{140}$ Quoting from Norton v. Larney, 45 S.Ct. 145, 148, 266 U.S. 511, 517, 69 L. Ed. 413 (1925).
} 
Alternative grounds for a particular judgment may be given full preclusive effect. "The courts will not attempt to discern which ground was the necessary one when either would support the judgment. In this situation, it is presumed that the court fully considered all the issues raised and the losing party had a full incentive to obtain appellate review. Consequently, there is not the same concern about whether there was a full opportunity and incentive to litigate all the adverse findings" (Friedenthal, 1999: \14.9).

\subsection{Persons Bound by Prior Judgment}

\subsubsection{Introduction}

Sections 7.1 through 7.3 explained the basic rules governing preclusion. With those rules in mind, the next important question focuses on the identification of persons affected by preclusion. In other words, who is bound by the judgment and who may take advantage of it. The most fundamental rule of preclusion asserts that parties to a prior action are bound while nonparties to the prior action are not (Wright and Miller and Cooper, 1981: \4449). In the terminology of older cases, it was held that a judgment was binding only on parties and persons in "privity" with them. Further, the older case law held that "the principle of mutuality conferred the preclusion benefits of a favorable judgment only on persons who would have been bound by an unfavorable judgment, apart from special rules for derivative liability relationships" (Wright and Miller and Cooper, 1981: \4449). However, the twin doctrines of "privity" and "mutuality" have both fallen out of favor in recent res judicata jurisprudence law. In their place, the courts have employed a more "functional analysis" so that, rather than examining whether parties are in privity, more recent court decisions instead focus the inquiry on the "reasons for holding a person bound by a judgment" (Wright and Miller and Cooper, 1981: \4448). Since most of the problems resulting in substantial litigation have occurred with respect to nonparties, and the circumstances in which nonparties can be bound, despite the "general rule" that states they are not, the next section shall deal with that issue and will be explored in the context of a fairly recent Supreme Court decision that dealt with these problems. 


\subsubsection{Principal Situations in Which Nonparties May be Bound by Prior Judgment}

In Taylor v. Sturgell141 the Supreme Court discussed the doctrine of res judicata and in particular, addressed the question of when nonparties are bound by a prior judgment. The Court was asked to adopt a "virtual representation" exception to the claim preclusion rules. The facts of the case are as follows. Greg Herrick, an antique aircraft enthusiast seeking to restore a vintage airplane manufactured by the Fairchild Engine and Airplane Corporation (hereinafter "FEAC"), filed a Freedom of Information Act (hereinafter "FOIA") request asking the Federal Aviation Administration (hereinafter "FAA") for copies of technical documents related to the airplane. The FAA denied Herrick's request, based on FOIA's exemption for trade secrets. Herrick took an administrative appeal, but when respondent Fairchild, FEAC's successor, objected to the documents' release, the FAA adhered to its original decision. Herrick then filed an unsuccessful FOIA lawsuit to secure the documents. ${ }^{142}$ Less than one month after that suit was resolved, petitioner Brent Taylor, Herrick's friend and an antique aircraft enthusiast himself, made a FOIA request for the same documents Herrick had unsuccessfully sued to obtain. When the FAA failed to respond, Taylor filed suit in the U.S. District Court for the District of Columbia. ${ }^{143}$ Holding the suit barred by claim preclusion, the District Court granted summary judgment to the FAA and to Fairchild, as intervenor in Taylor's action. The court acknowledged that Taylor was not a party to Herrick's suit, but held that a nonparty may be bound by a judgment if s/he was "virtually represented" by a party. The D.C. Circuit affirmed, 144 announcing a five-factor test for "virtual representation." The first two factors of the D.C. Circuit's test - "identity of interests" and "adequate representation" - are necessary but not sufficient for virtual representation. In addition, at least one of three other factors must be established: "a close relationship between the present party and his putative representative," "substantial participation by the present party in the first case," or "tactical maneuvering on the part of the present party to avoid preclusion by the prior judgment." The D.C. Circuit acknowledged the absence of any indication that Taylor

\footnotetext{
141553 U.S. 880, 128 S. Ct. 2161, 171 L. Ed. 2d (2008).

${ }^{142}$ Herrick v. Garvey, 200 F.Supp.2d 1321 (D.Wyo.2000) (The District Court granted summary judgment in favor of the FAA.). On appeal, the Tenth Circuit affirmed the grant of summary judgment. See, Herrick v. Garvey, 298 F. 3d 1184 (C.A.10 2002).

143 Taylor v. Blakey, U.S. Dist. Court of the District of Columbia (No. 03cv00173).

${ }^{144}$ Taylor v. Blakey, 490 F. 3d 965 (D.C. Cir. 2007).
} 
participated in, or even had notice of, Herrick's suit. It nonetheless found the "identity of interests," "adequate representation," and "close relationship" factors satisfied because the two men sought release of the same documents, were "close associates," had discussed working together to restore Herrick's plane, and had used the same lawyer to pursue their suits. Because these conditions sufficed to establish virtual representation, the court left open the question whether Taylor had engaged in tactical maneuvering to avoid preclusion.

The U.S. Supreme Court granted certiorari ${ }^{145}$ to resolve the disagreement among the Circuit Courts of Appeal over the permissibility and scope of preclusion based on "virtual representation." 146 The Court began its analysis by observing, "It is a principle of general application in Anglo-American jurisprudence that one is not bound by a judgment in personam in a litigation in which he is not designated as a party or to which he has not been made a party by service of process."147 The Court also observed that in order to temper this basic rule, it had recognized several exceptions including, for example, class actions, where "a person not named as a party may be bound by a judgment on the merits of the action, if she was adequately represented by a party who actively participated in the litigation."148 In the case before it, however, the Court was confronted with an issue of first impression, namely, whether there should a "virtual representation" exception to the general rule against precluding nonparties. Aside from the fact that the specific issue of virtual representation is interesting, the Supreme Court's analysis in Taylor is of particular helpfulness in this paper, as the Court did an excellent job not only of succinctly cataloguing the various (accepted) exceptions to the general rule of nonpreclusion to nonparties but also summarizing the general principles of res judicata jurisprudence in federal courts. The salient rules and principles articulated by the Court are set forth next.

\footnotetext{
145552 U.S. 1136, 128 S. Ct. 977, 169 L. Ed. 2d (2008).

146 The Court noted that the Ninth Circuit applies a five-factor test similar to the D.C. Circuit's. See Kourtis v. Cameron, 419 F.3d 989, 996 (2005). The Fifth, Sixth, and Eleventh Circuit, like the Fourth Circuit, have constrained the reach of virtual representation by requiring, inter alia, the existence of a legal relationship between the nonparty to be bound and the putative representative. See, Pollar v. Cockrell, 578 F. 2d 1002, 1008 (C.A.5 1978); Becherer v. Merrill Lynch, Pierce, Fenner \& Smith, Inc., 193 F. 3d 415, 424 (C.A.6 1999) (en banc); EEOC v. Pemco Aeroplex, Inc., 383 F. 3d 1280, 1289 (C.A.11 2004). The Seventh Circuit, in contrast, has rejected the doctrine of virtual representation altogether. See, Perry v. Globe Auto Recycling, Inc., 227 F. 3d 950, 953 (2000).

147 Taylor, supra 553 U.S. at 884, quoting Hansberry v. Lee, 311 U.S. 32, 40, 61 S.Ct. 115, 85 L.Ed. 22 (1940). 148 Id.
} 
Referring to its decision in Semtek Int'l Inc. v. Lockheed Martin Corp., ${ }^{149}$ the Court stated that the "preclusive effect of a federal-court judgment is determined by federal common law" and that [f]or judgments in federal-question cases - for example, Herrick's FOIA suit - federal courts participate in developing a 'uniform federal rules[s]' of res judicata, which this Court has ultimate authority to determine and declare."150 The Court also observed that its federal common law dealing with preclusion is subject to the constraints of due process of law. ${ }^{151}$ Claim preclusion and issue preclusion, which taken together comprise the doctrine known as res judicata, define the preclusive effect of a judgment. 152 "Under the doctrine of claim preclusion, a final judgment forecloses 'successive litigation of the very same claim, whether or not relitigation of the claim raises the same issues as the earlier suit." 153 In contrast to claim preclusion, issue preclusion bars "successive litigation of an issue of fact or law actually litigated and resolved in a valid court determination essential to the prior judgment." 154 This result obtains "even if the issue recurs in the context of a different claim." 155 "By "preclud[ing] parties from contesting matters that they have had a full and fair opportunity to litigate,' these two doctrines protect against 'the expense and vexation attending multiple lawsuits, conserve[s] judicial resources, and foster[s] reliance on judicial action by minimizing the possibility of inconsistent decisions."'156 In explaining the due process implications attendant to res judicata jurisprudence, the Court noted that persons not a party to litigation typically have not had a full and fair opportunity to litigate claims and issued resolved in that suit and consequently the doctrine of preclusion, whether claim or issue, "thus runs up against the 'deep-rooted historic tradition that everyone should have his own day in court."” 157

\footnotetext{
149531 U.S. 497, 507-508, 121 S. Ct. 1021, 149 L. Ed. 2d 32 (2001).

150 Taylor, supra 553 U.S. at 891, quoting in part from Semtek, supra 531 U.S. at 508. The Court observed in fn. 4 that "For judgments in diversity cases in contradistinction to federal question cases], federal law incorporates the rules of preclusion applied by the State in which the rendering court sits."

151 Id., citing, Richards v. Jefferson County, 517 U.S. 793, 797, 116 S. Ct. 1761, 135 L. Ed. 2d 76 (1996).

152 Id., 553 U.S. at 892. Discussing the often times difficult matter of terminology, the Court observed in fn 5 that "These terms have replaced a more confusing lexicon. Claim preclusion describes the rules formerly known as 'merger' and 'bar,' while issue preclusion encompasses the doctrine once known as 'collateral estoppel' and 'direct estoppel.”' Citing to, Migra v. Warren City School Dist. Bd. of Ed., 465 U.S. 75, 77 n. 1, 104 S. Ct. 892, 79 L. Ed. 2d 56 (1984).

153553 U.S. 892, citing to New Hampshire v. Maine, 532 U.S. 742, 748, 121 S. Ct. 1808, 149 L. Ed. 2 d 968 (2001).

154 Id.

155 Id.

156 Id., quoting, Montana v. United States, 440 U.S. 147, 153-154, 99 S. Ct. 970, 59 L. Ed. 2d 210 (1979).

${ }^{157}$ Id. 553 U.S. 892-893, quoting, Richards, 517 U.S., at 798, 116 S. Ct. 1761.
} 


\subsubsection{Primary Exceptions}

Having thus set forth the basic rules of preclusion, and their due process implications, the Court then launched into a discussion of the six most widely recognized exceptions to the general rule against nonparty preclusion. The first such exception applies to persons that consent to be bound by the determination of issues in an action between others. In such situations, a party who consented is bound in accordance with the terms of his agreement. ${ }^{158}$ The Court provided an illustrative example of when preclusion by consent might occur. "[ $[\mathrm{f}$ separate actions involving the same transaction are brought by different plaintiffs against the same defendant, all the parties to all the actions may agree that the question of the defendant's liability will be definitely determined, one way or the other, in a 'test' case" (Shapiro, 2001: 77-78). ${ }^{159}$ Another example of parties agreeing to be bound by consent occurred in Sampson v. Sony, ${ }^{160}$ where, in parallel patent litigation, the parties agreed by stipulation to be bound by the judgment in another designated action. Sampson later attempted to circumvent the stipulation on various grounds, but those attempts were rejected both by the trial judge and then the Second Circuit Court of Appeals. As stated by Wright, Miller and Cooper "[C]onsent is most likely to be given to avoid the costs of independent litigation, particularly in cases in which the absence of substantial factual disputes will enhance the stare decisis effect of the first judgment" (Wright and Miller and Cooper, 1981: \4453)..$^{161}$

The second recognized exception to nonparty preclusion is justified on the basis of various pre-existing "substantive legal relationships" between the person to be bound and a party to the judgment (Shapiro, 2001: 78). ${ }^{162}$ "Qualifying relationships include, but are not limited to, preceding and succeeding owners of property, bailee and bailor, and assignee and assignor. These exceptions originated 'as much from

\footnotetext{
158 Id. 553 U.S. 893, citing, Restatement Second (see, n. 3, \40).

${ }^{159}$ California v. Texas, 459 U.S. 1096, 1097, 103 S.Ct. 714, 74 L. Ed. 2 d 944 (1983) (dismissing certain defendants from a suit based on a stipulation that "each of said defendants [. . .] will be bound by a final judgment of this Court" on a specified issue."

${ }_{160}$ Sampson v. Sony Corp. of America, 434 F. 2d 312 (C.A.2 1970).

${ }^{161}$ See also, Westwood Chem., Inc. v. Johns-Manville Fiber Glass, Inc., 447 F. 2d 1160 (C.A.6 1973) (stipulation in parallel patent infringement setting in which several defendants in several independent actions were claiming infringement of the same patent; and where they agreed in the stipulation that the action as to one defendant should be tried first and that the final decision as to validity would be "final and binding upon all parties hereto to the same extent as if the defendant were a party to said case" upheld and given claim preclusive effect.)

162553 U.S. 894, quoting Richards, 517 U.S. at 798, 116 S. Ct. 1761.
} 
the needs of property law as from the values of preclusion by judgment" (Wright and Miller and Cooper, 1981: \4448). ${ }^{163}$

Thirdly, in Taylor, the Court observed that the Supreme Court has confirmed that "in certain limited circumstances" a nonparty may nevertheless be bound by a judgment if she was "adequately represented by someone with the same interests who [wa]s a party" to the former suit. ${ }^{164}$ Representative litigation that might have "preclusive effect on nonparties include properly conducted class actions ... and suits brought by trustees, guardians, and other fiduciaries." 165 In Richards v. Jefferson County, ${ }^{166}$ a case involving a legal challenge to the county's occupation tax, the Court began its decision by citing its earlier decision in Hansberry v. Lee, ${ }^{167}$ where the Court held that it would violate the Due Process Clause of the Fourteenth Amendment to bind litigants to a judgment rendered in an earlier litigation to which they were not parties and in which they were not adequately represented. In the course of its analysis, the Richards Court observed that the various due process concerns that implicate res judicata analysis "do not always require one to have been a party to a judgment in order to be bound by it. Most notably, there is an exception when it can be said that there is 'privity' between a party to the second case and a party who is bound by an earlier judgment. For example, a judgment that is binding on a guardian or trustee may also bind the ward or the beneficiaries of a trust."

Since class action litigation in America is prevalent, and has expanded to the EU, some additional discussion of res judicata in this area of law is warranted. As stated by Mullenix, "Americans seemingly love their class actions. The American class action has been a fixture in the federal procedural toolbox for over seventy-five years and has become a central feature of American procedural exceptionalism" (Mullenix, 2014: 399).168 According to Mullenix, "This narrative of American procedural

\footnotetext{
${ }^{163}$ In fn. 8 the Taylor Court explained that "The substantive legal relationships justifying preclusion are sometimes collectively referred to as 'privity.' See e.g., Richards, 517 U.S. 793, 798, 116 S.Ct. 1761, 135 L. Ed. 2d 76 (1996); Restatement Second (see, n. 3 at $\$ 62, \mathrm{cmt}$ a). The term 'privity,' however, has also come to be used more broadly, as a way to express the conclusion that nonparty preclusion is appropriate on any ground. See, Wright and Miller and Cooper, 1981: \4449, "To ward off confusion, we avoid using the term 'privity' in this opinion."

${ }_{164}$ Id. 553 U.S. 894, quoting Richards, 517 U.S., at 798, 116 S. Ct. 1761.

165 Id. 553 U.S. 894-895; citing to Martin v. Wilks, 490 U.S. 755, 762, n. 2, 109 S. Ct. 2180, 104 L. Ed. 2 d 835 (1989) (citing to Fed. Rule Civ. Proc. 23); and to Sea-Land Services, Inc. v. Gaudet, 414 U.S. 573, 593, 94 S.Ct. 806, 39 L. Ed. $2 d 9$ (1974); and to Restatement First of Judgments $\ 41$.

166517 U.S. 793 (1996).

167311 U.S. 32, 37 (1949).

168 Citing Marcus, R. (2014); See also Mullenix, 2010: 41.
} 
exceptionalism posits that the American justice system is not only the best in the world but that American procedural rules and its jury system are superior to comparative civil and common law systems abroad." 169 The class action mechanism, until recently, "was a uniquely American innovation, resisted (if not rejected) by most foreign legal systems."'170 Today, many European states in fact have laws and rules permitting class actions, ${ }^{171}$ even if the rules are at substantial variance from those in the United States. ${ }^{172}$

As articulated by Wright and Miller, "Preclusion by representation lies at the heart of the modern class action developed by such procedural rules as Civil Rule 23. Rule 23(b) recognizes several distinct types of class actions. While the types vary, [t]he central purpose of each of the various forms of class action is to establish a judgment that will bind not only the representative parties but also all nonparticipating members of the class designated by the court" (Wright and Miller and Cooper, 1981: \4455). Class action litigation advances a host of desirable judicial interests. It allows groups of litigants to pursue claims that any given individual or even several individuals could not afford to pursue. It avoids the multiplicity of actions and inconsistent adjudications. But as aptly observed by commentators, "Preclusion is appropriate, however, only if the class action provides a suitable substitute for individual litigation. The most important requirement of preclusion is that the named parties afford adequate representation. Any substantial divergence of interests defeats the ability of the named parties to represent absent class members, at least with respect to subjects touched by the divergence of interests. Even if there is no divergence of interests, the representatives must provide representation that is in fact adequate."173

\footnotetext{
${ }^{169} \mathrm{Id}$.

${ }^{170}$ Id., citing, Cappalli and Consolo, 1992: 218-219 (documenting European resistance to and rejection of American style class action litigation, referring to it as a kind of Rube-Goldberg procedural contraption). For the uninformed, a Rube Goldberg machine, named after American cartoonist Rube Goldberg, is a machine intentionally designed to perform a simple task in an indirect and overly complicated way. To put it bluntly, these authors were not complimentary of the American class action mechanism by any stretch of the imagination.

${ }^{171}$ For an excellent and exhaustive study of collective actions in Europe, and the push for EU-wide collective actions, the reader is referred to, Nagy, C. I. (2019): European Models of Collective Actions in Collective Actions in Europe, A Comparative, Economic and Transsystemic Analysis. The authors state that the history of collective actions in Europe started approximately three decades ago, but gained significant momentum in the mid-1990s. Today, 17 out of the 28 EU Member States provide for collective actions and of that number 10 of them have a system, or partial system based on the opt-out principle as used in the United States.

172 See, Class Actions in Europe and the United States, by Libralex E.E.I.G. Can be accessed at www.libralex.com (accessed 5. 12. 2020).

${ }^{173}$ Id.
} 
In the Hansberry ${ }^{174}$ case, the Supreme Court, after stating the general rule that a judgment binds only parties to an action, went on to observe that "there is a recognized exception that, to an extent not precisely defined by judicial opinion, the judgment in a 'class' or 'representative' suit, to which some members of the class are parties, may bind members of the class or those represented who were not made parties to it." Pursuant to Rule 23(c)(2) class members who properly avail themselves of an opportunity to "opt out" of the class action are not bound by the judgment or settlement. ${ }^{175}$ Similarly, nonmembers of the class are not bound. ${ }^{176}$

Although class action preclusion is subject to all of the requirements that apply to both issue and claim preclusion in individual actions, as already discussed, it is important to note that there are "[n]otice requirements peculiar to class actions [that] may also defeat preclusion. Failure to provide notice required by the due process clause or court rule will defeat preclusion without more" (Wright and Miller and Cooper, 1981: \4455). ${ }^{177}$ Due process of law requires not only adequate notice, but importantly, adequate representation, if principles of preclusion are to apply to a judgment entered in a class action case. The Supreme Court has held that there can be no preclusion to nonparties in situations where there was representation in the first action by parties that had interests hostile to the nonparties in terms that go to the very existence of a class. ${ }^{178}$ Furthermore, as observed by Wright and Miller, "[p]roblems of adequate representation arise in part because the named plaintiffs in a plaintiff class initially nominate themselves to represent the class. Judicial confirmation, even according to careful criteria of adequacy, cannot always ensure good litigation [. . .] extraordinary care must be taken to ensure adequate representation. Beyond the obvious problems of reluctant representatives, substantially divergent interests may underlie apparently common positions" (Wright and Miller and Cooper, 1981: \4455).

\footnotetext{
${ }^{174}$ Hansberry v. Lee, 61 S. Ct. 115, 118, 311 U.S. 32, 41, 85 L. Ed. 22 (1940).

175 See e.g., In re Transocean Tender Offer Securities Litigation, 427 F. Supp. 1211, 1217-1218 (D.C.Ill. 1977).

176 See, Restatement Second (see, n. 3 at $\ 42$, cmt. d, Illustration 7).

177 Citing, Penson v. Terminal Transport Co., 634 F. 2d 989 (C.A.5 1981) (Once a District Court has determined to permit individual class members to opt out of a consent judgment approved in an action certified under Civil Rule 23(b)(2), it is obligated to provide notice of the right to opt out. A class member who had been provided inadequate notice thus was not precluded by the consent judgment from seeking individual relief in a subsequent action.

${ }^{178}$ Hansberry, 61 S. Ct. at 119-120, 311 U.S. at 44-46.
} 
Given the many possible limitations on preclusion in the class judgment setting, it has been said that "the court conducting the [class] action cannot predetermine the res judicata effect of the judgment." 179 As observed by Wright and Miller, ${ }^{180}$ "[e]ven though a court hearing a class action may at times undertake to reject an assertion that the judgment will not be binding on nonparticipating class members, final enforcement of preclusion ordinarily occurs only with the decision of the court hearing a later action. The class action court can easily defeat preclusion, however, either by adopting a narrow class definition to ensure adequate representation or by decertifying the class at the close of trial on the ground that the class was not adequately represented" (Wright and Miller and Cooper, 1981: \4455). ${ }^{181}$

The fourth recognized exception to the general rule against nonparty preclusion involves cases where the nonparty "assumed control" over the litigation in which that judgment was rendered. ${ }^{182}$ The rationale for this exception is that in such cases the nonparty who assumed control had "the opportunity to present proofs and argument" and accordingly already "had his day in court" notwithstanding the fact such nonparty was not in fact a formal party to the prior litigation. ${ }^{183}$ Regarding the amount of control required on the part of the nonparty so as to be bound, and regarding common examples of relationships that most frequently arise in this setting, Wright and Miller observed, “The appropriate measure of control does not require that the named party or parties totally abandon control to the nonparty. Instead, it should be enough that the nonparty has the actual measure of control or opportunity to control that might reasonably be expected between two form coparties. Such relationships between a party and a nonparty are most often found when a liability insurer assumes control of a defense, an indemnitor participates in defending an action brought against its indemnitee, or the owners and officers of a

\footnotetext{
${ }^{179}$ Gonzales v. Cassidy, 474 F. 2 d 67, 74 (C.A.5 1973), quoted in Wright, C. A., Miller, A. R. \& Cooper E. H. (1981): Federal Practice and Procedure: Jurisdiction $\ 4455$. See also, Advisory Committee Note, Rule 23, 1966, 39 F.R.D. 69, 95, 106; Vol. 7A, S1789.

180 See, Wright and Miller and Cooper, 1981: \4455, citing EEOC v. Datapoint Corp., 570 F. 2d 1264, 1268 (C.A.5 1978).

${ }^{181}$ Citing, Grigsby v. North Mississippi Medical Center, 586 F. $2 d 457$ (C.A.5 1978); Roman v. ESB, Inc., 550 F. 2d 1343 (C.A.4 1976).

182 Id. 553 U.S. 895; citing, Montana, 440 U.S. at 154, 99 S. Ct. 970; Schnell v. Peter Eckrich \& Sons, Inc., 365 U.S. 260, 262, n. 4, 81 S.Ct. 557, 5 L. Ed. 2d 546 (1961); Restatement First (see, n. 2 at $\$ 39$ ).

183 Id.
} 
closely held corporation control corporate litigation" (Wright and Miller and Cooper, 1981: \4451). ${ }^{184}$

The fifth exception provides that a party bound by a judgment may not avoid its preclusive effect by attempting to relitigate by use of a proxy. 185 "Preclusion is thus in order when a person who did not participate in a litigation later brings suit as the designated representative of a person who was a party to the prior adjudication" (Wright and Miller and Cooper, 1981: \4454). ${ }^{186}$ In dicta, the Taylor Court also noted that while the Court had not yet had the occasion to squarely address the issue, "it also seems clear that preclusion is appropriate when a nonparty later brings suit as an agent for a party who is bound by a judgment" (Wright and Miller and Cooper, 1981: \4449).

The final established category of exceptions consists of certain circumstances where a special statutory scheme may "expressly foreclose successive litigation by nonlitigants [. . .] if the scheme is otherwise consistent with due process." 187 Bankruptcy and probate proceedings are illustrative examples of such schemes along with quo warranto 188 actions or other suits that "under [governing] law, [may] be brought only on behalf of the public at large." 189

\subsubsection{Taylor Court Rejects Virtual Representation Theory}

Having discussed the generally accepted exceptions to the rule against nonparty preclusion, the Court then turned its attention to whether it should uphold the D.C. Circuit's recognition of a broad "virtual representation" exception to the rule against nonparty exclusion. The D.C. Circuit purported to ground its doctrine in some prior

\footnotetext{
${ }^{184}$ See, fn. 9-12 and cases cited therein; See e.g., Hyman v. Regenstein, 258 F. 2d 502, 511-512 (C.A.5 1958) certiorari denied, 79 S. Ct. 589, 359 U.S. 913, 3 L. Ed. 2 d 575 (litigation losses by a corporation precluded its president, who indirectly owned a majority interest and who had directed and controlled the earlier litigation.)

185553 U.S. 895.

186 Id. citing, Chicago, R.I. \& P.R. Co. v. Schendel, 270 U.S. 611, 620, 623, 46 S.Ct. 420 , 70 L. Ed 757 (1926).

${ }^{187}$ Id. quoting Martin, 490 U.S., at 762, n. 2, 109 S. Ct. 2180.

${ }^{188}$ Historically, in both British and American common law, quo warranto (Medievel Latin for "by what warrant?") was a prerogative writ requiring the person to whom it was directed to show what authority they had for exercising some right, power, or franchise they claimed to have held. Today, in the United States, quo warranto usually arises in a civil case as a plaintiff's claim (and thus a "cause of action" instead of a writ) that some governmental or corporate official was not validly elected to that office or is wrongfully exercising powers beyond (or ultra vires) those authorized by statute of by the corporation's charter. In some jurisdictions that have enacted judicial review statutes, the prerogative writ of quo warranto has been abolished. See, discussion of Quo warranto at en.m.wikipedia.org (accessed: 5. 12. 2020).

${ }^{189}$ Id. quoting Richards, 517 U.S., at 804, 116 S. Ct. 1761.
} 
Supreme Court's statements that, in some circumstances, a person may be bound by a judgment if she was adequately represented by a party to the proceeding yielding that judgment. However, the Taylor Court observed that the D.C. Circuit's definition of "adequate representation" strayed from the meaning the Supreme Court had attributed to that term. In the Richards case, for example, the Alabama Supreme Court had held a tax challenge barred by a judgment upholding the same tax in a suit by different taxpayers. ${ }^{190}$ However, in that case the Supreme Court reversed, holding that nonparty preclusion was inconsistent with due process under circumstances where there was no showing (1) that the court in the first suit "took care to protect the interests" of absent parties, or (2) that the parties to the first litigation "understood their suit to be on behalf of absent [parties]." The Taylor Court concluded that in holding that representation can be "adequate" for purposes of nonparty preclusion even where these two factors are absent, the D.C. Circuit in the instant matter misapprehended Richards. ${ }^{191}$

Both Fairchild and the FAA advocated that the Supreme Court should abandon completely the attempt to delineate discrete grounds and clear rules for nonparty preclusion, and instead adopt an equitable and heavily fact-driven inquiry that would determine situations in which nonparty preclusion is appropriate. The Taylor Court declined this invitation. ${ }^{192}$ First, the Court noted that the proposed balancing test was at substantial odds with the constrained approach advanced by earlier Supreme Court precedent on the subject, such as Richards, ${ }^{193}$ which sought to delineate discrete, limited exceptions to the fundamental rule that a litigant is not bound by a judgment to which she was not a party. Secondly, the Court reasoned that "A party's representation of a nonparty is 'adequate' for preclusion purposes only if, at a minimum: (1) the interests of the nonparty and her representative are aligned, ${ }^{194}$ and (2) either the party understood herself to be acting in a representative capacity or the original court took care to protect the interests of the nonparty." 195 Additionally, the Taylor Court noted, adequate representation may also require notice of the original suit to the persons alleged to have been represented. ${ }^{196}$ The Court further observed

\footnotetext{
190 Id., at 795-797.

191 Taylor, 553 U.S. at 897.

192 Id. 553. U.S. at 898.

${ }^{193} \mathrm{Id}$.

194 Id., 553 U.S., at 900 citing Hansberry, supra, 311 U.S., at 43.

${ }^{195}$ Id., citing Richards, 517 U.S. at 798, 116 S. Ct. 1761, at 801-802.

${ }^{196}$ Id., citing Richards, 517 U.S. at 798, 116 S. Ct. 1761, at 801.
} 
that in the class-action context, these delineated limitations are insured by Rule 23 of the Federal Rules of Civil Procedure, and the various procedural safeguards contained therein. ${ }^{197}$ The Taylor Court was concerned, however, that an expansive virtual representation doctrine would recognize a common-law kind of class action lacking the procedural safeguards embedded in Rule 23.198 Additionally, the Taylor Court worried that a broad balancing test of the sort it was being asked to adopt for nonparty preclusion cases would likely complicate the already difficult task faced by the District Courts in deciding preclusion questions. ${ }^{199}$

Lastly, the FAA argued that nonparty preclusion should apply more expansively in "public-law" litigation than in "private-law" disputes. First, the FAA argued that the Richard's decision supported this view, when that Court acknowledged in that case that when a taxpayer challenges "an alleged misuse of public funds" or "other public action," the suit "has only an indirect impact on [the plaintiffs] interests" and that "the States have wide latitude to establish procedures [limiting] the number of judicial proceedings that may be entertained." 200 The Taylor Court disagreed, reasoning that in contrast to the public-law litigation contemplated in Richards, a successful FOIA action results in a grant of relief only to the individual plaintiff, rather than constituting a broad decree benefitting the public at large.201 Furthermore, the Court observed that the Richards Court said only that, for the type of public-law claims there envisioned, States were free to adopt procedures limiting repetitive litigation. ${ }^{202}$ The Court pointed out that while it is equally evident that Congress can adopt such procedures, it does not necessarily follow that the Court should proscribe or confine successive FOIA suits by different requesters. ${ }^{203}$ Secondly, the FAA argued that, because the number of plaintiffs in public-law cases is potentially limitless, it is theoretically possible for several persons to coordinate a series of vexatious repetitive lawsuits. Again, the Taylor Court rejected this

\footnotetext{
197 Id., 553 U.S. at 901.

${ }^{198}$ Id., The Taylor Court reasoned, "[V]irtual representation would authorize preclusion based on identity of interests and some kind of relationship between parties and nonparties, shorn of the procedural protections prescribed in Hansberry, Richards, and Rule 23. These protections, grounded in due process, could be circumvented were we to approve a virtual representation doctrine that allowed courts to "create de facto class actions at will."' Citing Tice v. American Airlines, Inc., 162 F. 3d 966, 973 (C.A.7 1998).

${ }_{199}$ Id., 553 U.S., at 901. Quoting from Bittinger v. Tecumseh Products Co., 123 F. 3d 877, 881 (C.A.6 1997), the Taylor Court stated: "'In this area of the law,' we agree, 'crisp rules with sharp corners' are preferable to a roundabout doctrine of opaque standards.",

${ }^{200}$ Id., 553 U.S., at 902 citing to 517 U.S. at 798, 116 S. Ct. 1761, at 803.

201 Id., at $902-903$.

${ }^{202}$ Id., at 903 , citing to Richards, 517 U.S. at 798, 116 S. Ct. 1761 , at 803.

${ }^{203}$ Id., 553 U.S., at 903.
} 
contention, stating that this risk does not justify departing from the usual nonparty preclusion rules. Stare decisis, the Court stated, will allow courts to dispose of repetitive suits in the same circuit, and even when stare decisis is not dispositive, "the human inclination not to waste money" should discourage suits based on claims or issues already decided (Shapiro, 2001: 97).204 In summary, the Taylor Court disapproved of the virtual representation theory of preclusion. ${ }^{205}$ "The preclusive effects of a judgment in a federal-question case decided by a federal court should instead be determined according to the established grounds for nonparty preclusion described in this [opinion]." 206

\section{Conclusion}

One commentator remarked that the Civil Rules are "one of the greatest contributions to the free and unhampered administration of law and justice ever struck off by any group of men since the dawn of civilized law" (Carey, 1943: 507). While this unquestionably is exaggeration, still, now 82 years after their adoption (along with many amendments) it has to be said that the Civil Rules were an amazing accomplishment and completely transformed civil procedure in the federal (and most state) courts. The fact they created a uniform procedure that at the same time has made pleading simpler, joinder of parties and claims easier, amendments freer, and discovery broader has had a sweeping impact on civil practice. As we have seen in the first sections of this paper, these rules have helped shape the form and entry of judgments and have provided clarity and certainty regarding when judgments are final so as to give them preclusive effect. Furthermore, because the rules have made it easier and more cost effective to join parties and claims in singular actions, the federal courts have greatly expanded the preclusive doctrines of claim and issue

\footnotetext{
204 Id., 553 U.S., at $903-904$.

205 Id., 553 U.S., at 904 . The remaining question in the case on appeal was whether the result reached by the courts below could be justified based on one of the six established grounds for nonparty preclusion. The Court noted that with one exception, those grounds had no application to this case. Respondents argued that Taylor's suit was a collusive attempt to relitigate Herrick's claim. The Taylor Court held that this argument justified a remand to allow the courts below the opportunity to determine whether the fifth ground for nonparty preclusion - preclusion because a nonparty to earlier litigation has brought suit as an agent of a party bound be the prior adjudication applied to Taylor's suit. However, while remanding the case, the Taylor Court cautioned that courts had to be cautious about finding preclusion based on agency principles, and that a mere whiff of "tactical maneuvering" will not suffice; instead, principles of agency law indicate that preclusion is appropriate only if the putative agent's conduct of the suit is subject to the control of the party who is bound be the prior adjudication.

${ }^{206} \mathrm{Id}$.
} 
preclusion, to the extent that America probably has the most expansive judgment preclusion in the world.

Judge Charles E. Clark, reputed to be one of America's greatest proceduralists, wrote in a 1945 dissenting opinion, "The defense of res judicata is universally respected, but actually, not very well liked." 207 But, that comment, shared by many at the time, was made only seven years after the adoption of the Rules. The tide has certainly shifted. In a 1981 decision in which a court of appeals had held that "simple justice" required that it should not hold a party barred by res judicata, Justice Rehnquist, writing for the Supreme Court, responded in a rebuke that "we do not see the grave injustice which would be done by the application of accepted principles of res judicata. 'Simple justice' is achieved when a complex body of law developed over a period of years is evenhandedly applied. The doctrine of res judicata serves vital public interests beyond any individual judge's ad hoc determination of the equities in a particular case." 208

This "new attitude" toward res judicata has been shaped to a large extent (if not totally) by the modern procedural notions found in the Civil Rules, which, as we have discussed, moved away from the harsh pleading requirements pre-Civil Rules, toward a system that greatly expanded the opportunity to present all of the contentions a party has in a single action. In sum, "Modern procedure has expanded the scope of the initial opportunity to litigate and this has made inevitable the narrowing of the situations in which a second opportunity to litigate need be given" (Wright and Miller and Cooper, 1981: \ 100A).209

The courts, however, continue to struggle with some of the outer contours of the preclusive effects of judgments, as has been demonstrated, for example, in the Taylor decision. In particular, there has been much litigation over preclusion in certain areas of the law, such as class action and intellectual property cases. And, the courts continue to struggle with striking an appropriate balance between, on the one

\footnotetext{
${ }^{207}$ Riordan v. Ferguson, 147 F. 2d 983, 988 (C.C.A. 2d 1945).

${ }^{208}$ Federated Department Stores, Inc. v. Moitie, 101 S.Ct. 2424, 2429, 452 U.S. 394, 401, 69 L. Ed. 2 d 103 (1981).

${ }^{209}$ Citing, Restatement Second, c. 1, at p. 10: "The rules of res judicata in modern procedure therefore may fairly be characterized as illiberal toward the opportunity for relitigation. Their rigor contrasts sharply with the liberality of the rules governing the original event, which is the theme of the Federal Rules of Civil Procedure and similar [systems]." That difference does not represent a contradiction or ambivalence in procedural policy. Rather, it reflects the relationship between rules of original procedure and rules of res judicata. Inasmuch as the former are now generally permissive, the latter are correspondingly restrictive."
} 
hand, setting preclusive rules that are relatively clear to follow so that litigants and the courts have sound guidance concerning when judgments have preclusive effect and, on the other hand, allowing some degree of flexibility in the rules to allow the courts to (equitably) remedy situations where employing res judicata might be fundamentally unfair. Again, the Taylor Court had to grapple with this dichotomy, although the Court ultimately came down firmly on the side of sticking with preclusive rules that are easier to apply in practice. A reasonable, wise decision in the author's view.

As the Civil Rules reach their one-hundredth anniversary in 2038 it will be interesting to track further claim preclusion decisions in the federal court system to see not only whether the courts continue to expand claim and issue preclusion but also how the courts deal with these doctrines given the ever-increasing variety and complexity of cases in which the doctrines must be applied.

\section{References}

Cappalli, B. R. and Consolo, C. (1992) Class Actions for Continental Europe? A Preliminary Inquiry, Temple International and Comparative Law Journal, 6(2), pp. 217-292.

Carey (1943) In Favor of Uniformity, Temple Law Quarterly, pp. 505-507.

Clermont, K. M. (2016) Res Judicata as Requisite for Justice, Rutgers University Law Review, 68(6), pp. 1107-1117.

Conway, M. D. (1993) Narrowing the Scope of Rule 13 [a], University of Chicago Law Review, 60, pp. $141-156$.

Currie, B. (1967) Mutuality of Collateral Estoppel: Limits of the Bernhard Doctrine, Stanford Law Review, 9(2), pp. 281-315.

Degnan, E. R. (1976) Federalized Res Judicata, Yale Law Journal, 85(6), pp. 741-773.

Field, H. R., et al. (2014) Materials for a Basic Course in Civil Procedure, University casebook series (Foundation Press: USA).

Friedenthal, J. H, Kane, M. K. and Miller, A.R. (1999) Civil Procedure, Third Edition (St. Paul: West Group).

Marcus, R. (2014) American Exceptionalism in Goals for Civil Litigation. In: Uzelac, A. (ed.), Goals of Civil Justice and Civil Procedure in Contemporary Judicial Systems (Heidelberg: Springer International Publishing), pp. 123-142.

Mullenix, S. L. (2014) Ending Class Actions as We Know Them: Rethinking the American Class Action, Emory Law Review, 64, p. 439-447.

Mullenix, S. L. (2010) American Exceptionalism and the Theory of Convergence: Are We There Yet?. In: Walker, J. and Oscar, G. C. (eds.): Common Law, Civil Law and the Future of Categories (LexisNexis).

Nagy, C. I. (2019) Collective Actions in Europe, A Comparative, Economic and Transsystemic Analysis (Heidelberg: Springer International Publishing).

Shapiro, D. (2001) Civil Procedure: Preclusion in Civil Actions, First edition (New York: Foundation Press). 
Spencer, B. A. (2015) The Form Had A Function: Rule 84 And the Appendix of Forms as Guardians of the Liberal Ethos in Civil Procedure, Nevada Law Journal, 15, pp. 1113-1140.

Vestal, D. A. (1967) Res Judicata/Preclusion by Judgment: The Law Applied in Federal Courts, Michigan Law Review, 66(8), pp. 1723-1724.

Wright, C. A., Miller, A. R. and Cooper E. H. (1981) Federal Practice and Procedure (St. Paul: West Group).

Wright, C. A., Miller, A. R. and Kane, M. K. (1986) Federal Practice and Procedure: Civil 2d (St. Paul: West Group).

\section{About the author}

Thomas Allan Heller, B.A., University of Michigan, J.D. Wayne Law, Michigan, United States of America is an Adjunct Professor and Senior Lecturer at the University of Maribor, Faculty of Law, Slovenia. 
